\title{
The Lifelong Learning Competencies of Trainers Who Work for Public Education Centres: Case of Mersin
}

\author{
Ufuk Cem KOMȘU*
}

Received: 02 August 2015

Accepted: 11 December 2015

\begin{abstract}
From the point of lifelong learning concept, gaining the required information and skills is crucial for trainers who work in public education centres. Determining the perception of lifelong learning competency of trainers in public education centres and how they differ on some demographical variables is the main purpose of this study. The Scale of Lifelong Learning Competencies was used for this descriptive study. To analyze the data, SPSS 22.0 was used to employ descriptive statistics such as frequencies, means and standard deviations and perform MannWhitney-U and Kruskall Whallis tests. The sample of survey consisted of 121 trainers of public education centres in Erdemli and Mezitli of Mersin. According to the main findings, the general lifelong learning competencies of the trainers were found to be at a high level. Additionally, participants' level of education and the perception of general lifelong learning competencies, competencies of learning to learn, acquiring information, digital and decision-making significantly differed on participants' level of education and ages.
\end{abstract}

Keywords: public education centre, lifelong learning, training of trainers, competencies of lifelong learning.

\section{Extended Abstract}

Purpose and Significance: As mentioned commonly, globalisation and its consequences lead the societies to individual and non-formal learning and education concepts. In the circumstances of such era, individuals need a wide range of competencies for overcoming the challenges of contemporary world (Budak, 2009). Thus, increasing need for up-to-date information about professional and individual development emphasises the new requirements for professionals. Particularly, the professionals such as teachers, academics, instructors, trainers and all other learning and teaching based working professionals might be easily able to perceive their own inadequacies and competencies.

Lifelong learning approach has a potential of social cohesion through its basic facts. Focusing on the learning demands of individuals, assisting the personal development and increasing the social welfare by supporting development of learning skills are the typical objectives of lifelong learning policies (Uzunboylu \& Hürsen, 2011). In these contexts, some international organizations such as OECD and EU defined basic competencies which are expected to be functional and essential in lifelong activities as a basis of lifelong learning. In Turkey, as an element of non-formal learning and education, the public education centres play critical roles in both personal and social

\footnotetext{
* Corresponding Author: Dr., Mersin University, Mersin, Turkey, ucemkomsu@,mersin.edu.tr
}

\section{Citation Information}

Komşu, U. C. (2017). Halk eğitimi merkezlerinde görev yapan eğiticilerin yaşamboyu öğrenme yeterlikleri: Mersin örneği. Kuramsal Eğitimbilim Dergisi [Journal of Theoretical Educational Science], 10(1), 117-145. 
development processes. In order to support their essential contribution to educational system and lifelong learning, the teaching staff (mainly qualified instructors) must be promoted through leading them to participate lifelong learning activities and updating professional skills. Within this study, describing the lifelong learning competencies of qualified instructors who work for public education centres was determined. The main objectives of this research are determining the level of perception of lifelong learning competencies and its variations regarding age, education level, professional experience and seminar experience of the trainers in Erdemli and Mezitli public education centres.

Methods: In that descriptive research, the scale of Lifelong Learning Competencies was applied to 121 trainers of both the directorates of public education of Erdemli and Mezitli in April and May of 2015. The research population of the study is the trainers of public education centres in Mersin. The trainers in Erdemli and Mezitli public education centres are the sample of the research and 121 trainers were selected through the random sampling. The scale of Lifelong Learning Competencies which was developed by Uzunboylu and Hürsen (2011) was used for data collection. The scale is composed of 6 sub-dimensions and 51 items and its total value of coefficient of reliability of the cronbach alpha is 0,95. The obtained data was analyzed through SPSS 22.0 for Windows. In analyzing process, the tests of Mann-Whitney and Kruskal Whallis were applied for comparison and evaulation of relations between variables.

Results: The research findings show that the perceptions of general lifelong learning competencies of the trainers have been determined as high degrees including most of sub-dimensions except digital competencies. Second, statistically significant difference was detected between participants' age and competencies on acquiring information, digital competencies, competencies of decision making and general lifelong learning competencies. Thirdly, there is not statistically significant difference between their period of professional experience and the competencies of general lifelong learning, self-management, learning to learn, initiative-entrepreneurship and decision making. Besides, statistically significant difference was detected between participants' education level and the competencies of general lifelong learning, learning to learn, acquiring information, digital and decision making. Finally, statistically significant difference was found between the experience of participation in seminar previously and only the competencies of self-management.

Discussion and Conclusions: As a consequence of findings, it might be disscussed that, in spite of low level of education and insufficient professional experience, the trainers' perception of lifelong learning competencies was detected as very high. The reason for this might be their self-confidence perception. However, the participants' mean of digital competencies is the lowest of sub-dimensions. Therefore, it indicates that the trainers lack of digital skills and require computer and web-based training. 
The variable of age and the period of proffessional experience which is associated with the age, exhibited the most remarkable facts of the study. The participants' whose age are 35 and below have the highest scores of means of digital, decision making and acquring information competencies. It is estimated that the younger participants' skills of computer, communication and web using may prompt such results. Concordantly, it was found that the length of period of proffessional experience has no statiscally significant difference between the lifelong learning competencies. It was expected that the participants with longer experience period would have the highest competency degrees. Furthermore, the results show that the trainers who have less experience may perceive themselves as more competent in digital and acquring information than the others. Considering these results, there is a need for new investigations of relational aspects of competencies and demographical parameters. Particularly, the demographical and educational profiles of the trainers in public education centres require to be monitored and evaluated periodically. In spite of the results of that study indicate hopeful levels of lifelong learning competencies, it is critical to demonstrate and develop the learning tools of such staff in order to make them more competent in the world and deal with transformations. 


\title{
Halk Eğitimi Merkezlerinde Görev Yapan Eğiticilerin Yaşamboyu Öğrenme Yeterlikleri: Mersin Örneği
}

\author{
Ufuk Cem KOMŞU*
}

Makale Gönderme Tarihi: 02 Ağustos 2015

Makale Kabul Tarihi: 11 Aralık 2015

\begin{abstract}
ÖZ: Yaşamboyu öğrenme anlayışı çerçevesinde, bireylerin ihtiyaç duyduğu güncel bilgilerin ve becerilerin kazanılması, özellikle halk eğitimi merkezlerindeki eğitim personeli için kritik önem taşır. Bu çalışmada, halk eğitim merkezlerindeki eğiticilerin yaşamboyu öğrenme yeterlik algısının ve bazı demografik değişkenlere göre bu algının değişiminin belirlenmesi hedeflenmiştir. Betimsel bir araştırma niteliğindeki bu çalışmada, Yaşamboyu Öğrenme Yeterlikleri Ölçeği kullanılmıştır. Bulguların analizinde SPSS 22.0 programı kullanılmış olup, verilerin değerlendirilmesinde sıklık, yüzde, ortalama ve standart sapma değerlerinden yararlanılmış ve Mann-Whitney-U ile Kruskall Whallis testleri uygulanmıştır. Araştırmanın çalışma grubu, Mersin'in Erdemli ve Mezitli Halk Eğitimi Merkezlerindeki 121 eğitim personelinden oluşmaktadır. Bulgulara göre, eğiticilerin genel yaşamboyu öğrenme yeterlikleri algısı yüksek çıkmıştır. Katılımcıların eğitim düzeyi ile genel yaşamboyu öğrenme yeterlikleri algısı, öğrenmeyi öğrenme, bilgiyi elde etme, dijital ve karar verebilme yeterlikleri arasında ve katılımcıların yaşı ile bilgiyi elde etme, dijital yeterlikler, karar verebilme ve genel yeterlik puanları arasında istatistiksel açıdan anlamlı farklılık saptanmıştır.
\end{abstract}

Anahtar kelimeler: halk eğitimi merkezi, yaşamboyu öğrenme, eğiticilerin eğitimi, yaşamboyu öğrenme yeterlikleri.

\section{Giriş}

Yaşamboyu öğrenme ve yetişkin eğitimi olguları, eğitim alanyazınında ve uluslararası düzlemdeki tüm toplumsal gelişim çalışmalarında 1970'lerden itibaren ciddi düzeyde yoğunluk kazanmış durumdadır. Bunun nedenleri arasında örgün eğitim sistemlerinin yetersizlikleri, küreselleşme sürecinin sosyal devlet anlayışında yol açtığı değişim ve teknolojideki ilerlemeler gösterilebilmektedir (Budak, 2009). Günümüzün sosyo-ekonomik ve teknolojik koşullarında, toplumlardaki tüm kesimlerin öğrenme ve bilgi gereksiniminin artması kaçınılmazdır. Güncellenmiş bilgi açığg ve sürekli öğrenme ihtiyac1, öğretmenler ve akademisyenler gibi öğretme ve eğiticilik hizmetleriyle bağlantılı tüm meslek sahiplerini de kapsayan bir olgu haline dönüşmüştür.

$\mathrm{Bu}$ konudaki en kapsamlı metinlerden biri olan, Avrupa Komisyonu'nun 2002 yılında tanımlamış olduğu yaşamboyu öğrenme becerileri, yaşamboyu öğrenme ve yaşamboyu eğitim süreçlerinin temel işlevlerine ve kazanımlarına vurgu yapar. $\mathrm{Bu}$ beceriler, ana dilin kullanımından tüm iletişim becerilerine uzanan ve günümüz toplumsal yaşamına ilişkin birçok gereksinimin karşılanmasında kilit rol oynayan etkinlikleri kapsamakta (Uzunboylu \& Hürsen, 2011) ve içerdikleri yeterlik algısıyla, günümüz yaşamboyu öğrenme etkinliklerinin omurgasını tanımlamaktadır. Türkiye'de de, cumhuriyet döneminden itibaren toplumsal değişimin ve kalkınmanın bir aracı olarak işlevselleştirilen halk eğitimi hizmetleri, yaşamboyu öğrenme ve yetişkin eğitimi süreçlerinin ayrılmaz bir parçası olmuştur. Bu kurumlarda görev yapan eğiticilerin yaşamboyu öğrenme yeterliği algısı, Türkiye'nin yaşamboyu öğrenme politikalarının belirlenmesinde göz önüne alınması gereken etkenlerden sayılabilir. Nitekim, günümüz

\footnotetext{
* Sorumlu Yazar: Dr., Mersin Üniversitesi, Mersin, Türkiye, ucemkomsu@,mersin.edu.tr
} 
Türkiye'sinin örgün ve yaygın eğitim koşullarında, halk eğitim merkezlerinin yürütmekte olduğu hizmetlerin kapsamı ve işlevi, mesleki eğitim ve kişisel gelişim alanlarında yüklenmiş oldukları büyük sorumluluğu yansıtmaktadır. Bu çalışmada, halk eğitim merkezleri müdürlüklerinde kadrolu veya kadrosuz olarak görevlendirilen eğitim personelinin yaşamboyu öğrenme yeterlik algısının betimlenmesi hedeflenmiştir.

Çalışmanın araştırma amaçlarını ifade eden sorular şunlardır:

Araştırma sorusu-1: Halk eğitim merkezinde görev yapan eğiticilerin, yaşamboyu öğrenme yeterlik düzeyi algısı ne düzeydedir?

Araştırma sorusu-2: Halk eğitim merkezinde görev yapan eğiticilerin yaşamboyu öğrenme yeterlikleri algısı, yaş ve cinsiyet değişkenlerine göre farklılık göstermekte midir?

Araştırma sorusu-3: Halk eğitim merkezinde görev yapan eğiticilerin yaşamboyu öğrenme yeterlikleri algısı, mesleklerindeki deneyim süresine göre farklılık göstermekte midir?

Araştırma sorusu-4: Halk eğitim merkezinde görev yapan eğiticilerin yaşamboyu öğrenme yeterlikleri algısı, eğitim düzeyine göre farklılık göstermekte midir?

Araştırma sorusu-5: Halk eğitim merkezinde görev yapan eğiticilerin yaşamboyu öğrenme yeterlikleri algısı, bir eğitim seminerine katılmış olma deneyimine göre farkl1lık göstermekte midir?

\section{Halk Eğitimi Merkezleri ve Eğiticilerin Eğitimi}

Yaşamboyu öğrenmenin ve yetişkin eğitiminin kaçınılmaz ihtiyaçlar haline geldiği günümüzde, Milli Eğitim Bakanlığı'na bağlı olarak hizmet vermekte halk eğitim merkezlerinin konumunun ve işlevlerinin önemi artmaktadır. "Yaygın eğitim", "halk eğitimi" ve "non-formal eğitim" terimleriyle de anılmakta olan yetişkin eğitimi etkinlikleri, hem Avrupa Birliği ülkelerinde hem de Türkiye'de farklı kurumlar tarafından yürütülmekteyse de, birbirine paralel işlevleri taşımaktadır.

Yaşamboyu öğrenme ve yetişkin eğitimi kavramları, ülkelere göre değişen farklı tanımları ve uygulamaları içerir. Türkiye'deki eğitim sisteminin resmi ve idari yapılanması açısından, yetişkin eğitimi kapsamındaki yaygın eğitim çalışmaları temel eğitimi, meslek ve beceri kazandırmayı ve kişisel gelişimi sağlamayı kapsamaktadır (Sabancı \& Rodoplu, 2013). Dolayısıyla, halk eğitimi merkezlerinin, yaşamboyu öğrenme felsefesinin yaygın eğitim uygulamalarının odağında yer aldığı söylenebilir.

Türkiye İstatistik Kurumu'nun 2010 yılı verilerine göre, Türkiye'de açılmış olan yaygın eğitim kurslarında halk eğitim merkezleri en büyük paya sahiptir. 1999-2010 döneminde, Milli Eğitim Bakanlığı'na bağlı halk eğitim merkezlerinin sayısı \% 6 düzeyinde bir artış göstermiştir (Sabancı \& Rodoplu, 2013). 2013 yılında, Türkiye çapında düzenlenen tüm kursların \% 65'i, kapsamında halk eğitim merkezlerinin de bulunduğu kamu kurum ve kuruluşları tarafından düzenlenmiştir (Türkiye İstatistik Kurumu, 2013). Belediyeler, sivil toplum örgütleri ve özel eğitim kurumlarının da rol 
aldığı yetişkin eğitimi niteliğindeki eğitim etkinliklerinde, halk eğitimi merkezlerinin ve kamusal birimlerin ağırlı̆̆ı söz konusudur.

Türkiye'de, Milli Eğitim Temel Kanunu ve Yaygın Eğitim Kurumları Yönetmeliği çerçevesinde yürütülen yaygın eğitim hizmetleri, genel ve mesleki-teknik olmak üzere iki ayrı alanda gerçekleştirilmekte olup, bu hizmetlerden sorumlu olan halk eğitim merkezleri son düzenlemeyle Yaşamboyu Öğrenme Genel Müdürlügü'ne bağlanmıştır (Sabancı \& Rodoplu, 2013). Yaygın eğitim hizmetlerine ilişkin 21.05.2010 tarihli yönetmelikte, oldukça geniş bir kapsamı olan amaçlar tanımlanmıştır. Bu amaçlara bakıldığında, yaşamboyu öğrenme ve yaşamboyu eğitim olgularına yüklenmiş olan işlevler ve bunların başarılabilmesine dönük personel ve donanım altyapısının nitelikleri belirginleşmektedir. Yönetmelikte tanımlanmış olan yaygın eğitim amaçları, halk eğitim merkezlerinin görevleri olarak tanımlanmış faaliyetlere paralel bir yapıdadır. Bu görevlerin kapsadığı alanlar ve etkinlikler arasında yurttaşılık, aile, güzel sanatlar, spor, okuma-yazma, meslek öncesi eğitim, meslek edindirme eğitimi, işbaşında eğitim, engelli bireyler için eğitim, madde bağımlıları ile tutuklu ve hükümlüler için eğitim, çocuk psikolojisi ve bakımı, ergenlik ve gençlik psikolojisi ve ev yönetimi alanlarında eğitimler düzenlemek ve uzaktan eğitimle ilgili gelişmeleri izlemek yer almaktadır. Bunlara ek olarak, temel amaçlara uygun gezi, sempozyum, seminer, konferans, yarışma, sergi, panel ve benzeri etkinlikleri gerçekleştirmek, kitaplıklar kurmak, periyodik yayın yapmak, hayatboyu öğrenmeyi destekleyen ulusal ve uluslararası bilgi ağları oluşturmak ve yerel çevreye ait tarihi ve kültürel değerlerin tanıtılması için çalışmalar yapmak da görev ve sorumluluklar kapsamdadır (Milli Eğitim Bakanlığı, 2010; Türkoğlu \& Uça, 2011).

Görüldüğü üzere, toplumsal yaşamın neredeyse her alanına ilişkin eğitim süreçleriyle görevlendirilmiş olan halk eğitim merkezlerinin, bu kadar geniş bir görev alanına, sorumluluk yüküyle uyumlu personele ve donanım gücüne de sahip olması beklenir. Ancak, bu konuda yapılmış araştırmalar ve resmi raporlar, bu kurumların ciddi düzeyde yetersizliklerle karşı karşıya olduklarını göstermişstir.

$\mathrm{Bu}$ kapsamda belirtilebilecek temel sorunlar arasında bütçe yetersizliği, fiziksel koşulların yetersizliği, örgün ve yaygın eğitim bağlantılarının yetersizliği, personel yetersizliği ve program içeriklerinin yetersizliği sayılabilir. Özellikle personel yetersizliği konusu, birçok çalışmada ve raporda dile getirilmiş olup, hem yetişkin eğitimi alanında uzman olmayan bir öğretici kadrosuna hem de bu kadroların mesleki bilgilerinin yetersizliğine dikkat çekilmiştir (Türkoğlu \& Uça, 2011; Yayla, 2009). Yayla'nın (2009), Milli Eğitim Bakanlığı'na bağlı halk eğitim merkezlerinde görev yapan personeli kapsayan raporundaki sorunların ve ihtiyaçların eğitim personeliyle ilgili boyutu, yaşamboyu öğrenme ve eğitimin kamusal profili açısından dikkat çekicidir. Bu rapora göre, halk eğitim merkezlerinde görev yapan öğretmenler, diğer ülkelerin yetişkin eğitimi sistemleri hakkında bilgi sahibi olma, yabancı dil öğrenme, Avrupa Birliği ve Türkiye'deki yetişkin eğitimi çalışmaları hakkında bilgi alma, yetişkin eğitimi ilke ve yöntemleri ve toplum kalkınması ile yetişkin eğitiminin ilişkisi konularında hizmetiçi eğitime katılma gereksinimi duyduklarını belirtmiştir. 
Dolayısıyla, yaygın eğitimin kamu boyutundaki aktörler olan halk eğitim merkezlerinin personel öğesine ilişkin yetersizliklerin, yaşamboyu öğrenme ve yetişkin eğitimi yeterlikleri ve uygulamalarıyla birlikte değerlendirilmesi gerektiği açıktır. Nitekim, raporda dile getirilmiş olan öğrenme gereksinimleri de buna işaret etmektedir.

Halk eğitim merkezlerinin personel profilindeki eğitici kadrosu rehber öğretmen, kadrolu öğretmen, başka okullarda çalışan öğretmenler, kadrolu ve sözleşmeli usta öğreticiler, uzmanlar ile gönüllü öğreticilerden oluşmaktadır (Ural \& Akbaş, 2009). Bu düzeyde geniş bir dağılım sergileyen eğitici personelin öğrenme ihtiyaçlarını gözardı etmemek, kritik bir öneme sahiptir.

Sabancı ve Rodoplu (2013)'nun Antalya halk eğitim merkezleri araştırmasında, halk eğitim merkezlerinin denetlenmesiyle ilgili sorunlar incelenmiş, fiziksel şartlardan personel niteliklerine kadar değișen sorunların mekansal, donanımsal ve personel boyutlarıyla saptaması yapılmıştır. Araştırmamızın kapsamı açısından önem taşıyan bireyin denetimiyle ilgili sorunlara bakıldığında, eğiticilerin denetiminin yetersiz olduğu ve usta eğiticilere kişisel ve mesleki gelişim gibi konularda yeterli rehberlik ve destek hizmetlerinin verilmediği görülmüştür. Ural ve Akbaş'ın İstanbul'daki halk eğitim merkezlerinin yöneticilerini ve usta eğitici adaylarını kapsayan araştırma bulgularına göre, halk eğitim merkezlerindeki eğitici personelin seçim süreci etkin değildir. Nitelikli bir seçme-değerlendirme işleminin maliyet-fayda analizleri yapılmadan tecrübe ve sağduyuya dayalı olarak gerçekleştirilen görevlendirmeler, yeterliklerden uzak bir eğitici kadrosunun oluşumuna yol açmaktadır. Bu durum, çok farklı yaş gruplarından, mesleklerden, gelir ve eğitim düzeylerinden yetişkinlere hitap etmesi gereken eğiticilerin, yetişkin eğitimi etkinliklerini olumsuz etkilemesine neden olabilmektedir (Ural \& Akbaş, 2009).

Eğiticilerin eğitimi olgusu ise, eğitim alanyazınında ve araştırmalarında, eğitim süreçlerinin ayrılmaz parçası konumundadır. Hem mesleki eğitim hem de kişisel gelişim boyutlarıyla yaşamboyu öğrenme ve yetişkin eğitimi uygulamaları, mesleği gereği sürekli öğrenmek ve öğretmek durumunda olan bireylerin yaşamının doğal bir parçası olmalıdır. Dolayısıyla öğretmenlerin, akademisyenlerin ve halk eğitimi merkezi eğiticilerinin bireysel ve mesleki gelişimini kapsar. Öğrenme ve eğitim etkinliklerinin en sistemli ve programlı biçimde yürütüldüğü kurumlar olarak okullar, üniversiteler ve halk eğitim merkezleri, toplumdaki bireylerin yaşamboyu öğrenme becerilerinin bir bilimsel disiplin çerçevesinde aktarılabileceği ortamlar konumundadır. Bu ortamlardaki çalışmaların verimliliğinin, öğreticilerin bilgi ve beceri düzeyiyle bağlantılı olduğunu ileri sürmek yanlış olmayacaktır.

Örgün ve yaygin eğitim sistemindeki öğreticiler olarak, hem okullardaki hem de halk eğitimi merkezlerindeki eğitim personelinin yaşamboyu öğrenme sürecindeki temel sorumluluğu, öğrenenlerin yaşamboyu öğrenme becerilerinin geliştirilmesidir. Bu sorumluluğun başarılabilmesi için, öncelikle öğretmenlerin kendi yeterliklerini geliştirmesi kaçınılmazdır (Selvi, 2011). Başka bir deyişle, iyi bir eğitim sistemi ve başarılı öğrenciler için, öğretmen yetiştiren sistemlerin ve kurumların yeterliliği ve başarısı önemlidir. Böyle bir başarı, öğretmen yeterliklerini artıran ve öğretmenlerin 
kişisel ve mesleki gelişimini sürekli biçimde sağlayabilen (hizmetiçi eğitim gibi) mesleki eğitim programlarıyla sağlanabilir (Seferoğlu, 2004). Hizmetiçi eğitim anlayış1 çerçevesinde uygulanan her türlü eğitim uygulaması öğretmenlerin, akademisyenlerin ve usta öğreticilerin kişisel ve mesleki gelişimine katkı yapabilir. Milli Eğitim Bakanlığı'nın yaz dönemlerinde düzenlediği hizmetiçi eğitim kursları, bu konuyla ilgili klasik bir örnektir.

Akademik personelin eğitimine yönelik eğiticilerin eğitimi programlarına örneklerden biri, Hacettepe Üniversitesi örneğidir. 2006 yılında gerçekleştirilmiş olan bu uygulamada, tüm öğretim üyelerinin eğiticilik yeterliklerinin geliştirilmesi ve yaşamboyu öğrenme becerilerinin kazandırılması yoluyla öğrencilerin de bu becerilere yönlendirilmesi hedeflenmiştir (Soran, Akkoyunlu \& Kavak, 2006). 2000'li yıllarda, bazı önde gelen tıp fakültelerinde, öğretim üyelerinin eğitimine yönelik seminer çalışmaları da yaygınlaşmış; ders programlarının ve yöntemlerinin geliştirilmesine yönelik eğitim programlarından oldukça olumlu sonuçlar alındığ́ görülmüştür (Geyik, Kara, Uzunlar, Baltac1, Gönen, ve diğerleri, 2013).

Eğitici eğitiminin temelinde ve yaşamboyu öğrenme felsefesinin özünde, aile eğitimi modelleri de bulunmaktadır. Buna paralel olarak, halk eğitim merkezlerinde görev yapan eğiticilerin analık-babalık rolleri konusundaki yeterliliğinin, mesleki başarılarına da yansıması olanaklıdır. Nitekim, günümüz sosyo-ekonomik koşullarında, hem maddi sorunlar hem de aile yapısındaki değişimler nedeniyle, anne ve babaların oynamaları gereken roller konusunda eğitim alma gereksinimi de artmıştır. Bu kapsamda, Türkiye'de, kamu kurumlarının aile eğitimi projeleri de yaygınlık kazanmıştır (Kılıç, 2010). Anne ve babaların eğitiminde geliştirilen aileden aileye eğitim modeli de, eğitici annelerin yetiştirilmesine katkı sağlayabilir. Türkiye'de çok yeni bir yöntem olan aileden aileye eğitim uygulaması, yetişkin eğiticilerinin yetiştirilmesinde, öğrenme baskısının azaltılması yoluyla daha rahat bir öğrenme ortamının oluşturulmasını kolaylaştırabilmektedir (Demircioğlu \& Ömeroğlu, 2014). Kısacası, yaygın eğitim yönetmeliğinde tanımlanmış olan amaçlar ile halk eğitimi merkezleri için belirlenmiş olan görev alanının birbirini tamamlayacak biçimde çakışması, bu birimlerde görev yapan eğitim personelinin mesleki ve kişisel gelişim boyutlarının unutulmaması gerektiğinin bir göstergesidir. Eğiticilerin eğitimi ve hizmetiçi eğitim kavramları, yaşamboyu öğrenmenin ve yetişkin eğitimi uygulamalarının doğal bir parçası olduğundan, halk eğitimi merkezlerinin eğitim personelinin de bu kapsamda değerlendirilmesi doğaldır.

\section{Yaşamboyu Öğrenme Felsefesi ve Yaşamboyu Öğrenme Yeterlikleri}

Yaşamboyu öğrenme ve yaşamboyu eğitim kavramları hem bireysel hem de toplumsal boyutlarıyla, 1970'lerden itibaren eğitim alanyazınında ve ülkelerin eğitim politikalarında ayrılmaz bir öğe konumuna yükselmiştir. Sürekli bir değişim içerisindeki günlük yaşamın gerektirdiği öğrenme konuları, yaşamboyu öğrenme felsefesinin kapsadığı bazı becerileri gerekli kılar. UNESCO ve OECD gibi toplumsal yaşamın iyileştirilmesi ve geliştirilmesine ilişkin bazı misyonları temsil eden uluslararası kurum ve kuruluşlar da, yaşamboyu öğrenme ve yetişkin eğitimi kapsamındaki çalışmalara 
önem vermektedir. Yaşamboyu eğitim, bireylerin ilgisine yönelik ve yaşamboyu öğrenme firsatlarını sağlayabilecek bir örgütsel yapıyı ve bu hizmetlerin arzın1/sunumunu anlatan bir olgudur. Yaşamboyu öğrenme ise, bu yapının bireysel düzlemine odaklanmış olup, bireyin bilişsel, duyuşsal ve devinişsel açılardan tüm gereksinimlerini kapsayan ve okul öncesi dönemlerden başlayıp ölümüne dek uzanan formal ve informal öğrenmelerin tümünü içerir (Budak, 2009). Sönmez, yaşamboyu öğrenme olgusunu, "bireyin kendini geliştirmesine yönelik her tür öğrenme ortamından yararlanarak bilgi, beceri, tutum ve alışkanlıklar kazanmasını öngören bir anlayışın ifadesi", biçiminde tanımlamıştır. Candy'e göre yaşamboyu öğrenme ise, "bireylerin örgün eğitim sonrasında kendi eğitimlerine devam edebilmelerinde gerekli olan beceri ve yeterliklerle donatılmaları"nı kapsar (Akt. Konokman \& Yelken, 2014, s.268). Milli Eğitim Bakanlığı'nın hazırladığı Türkiye Hayat Boyu Öğrenme Strateji Belgesi'nde yer alan hayat boyu öğrenme tanımı ise, "kişisel, toplumsal, sosyal ve istihdam ile ilişkili bir yaklaşımla bireyin bilgi, beceri, ilgi ve yeterliklerini geliştirmek amacıyla hayatı boyunca katıldığı her türlü öğrenme etkinlikleri"dir. Ayrıca, bu etkinliklerin amacının "bireylerin bilgi toplumuna uyum sağlamaları ve bu toplumda yaşamlarını daha iyi kontrol edebilmeleri için ekonomik ve sosyal hayatın tüm evrelerine etkin bir biçimde katılımlarına imkan vermek" olduğu belirtilmiştir (Akt. Coşkun \& Demirel, 2012, s.109). Bu tanımlarda karşımıza çıkan kilit kavramlar ise "beceri" ve "yeterlik" olgularıdır.

Bireysel becerileri kapsayan bir kavram olan yeterlik olgusunun temelinde, bilişsel bir düzlem bulunur. Sosyal Bilişsel Kuram düşünceler, davranışlar ve çevresel faktörler gibi bireysel faktörlerin birbirleriyle etkileşimini vurgulayarak davranışları açıklar (McCoach \& Colbert, 2010). Yeterlik (efficacy) olgusu da, bu düzlemde karşımıza çıkan bir kavram olup, bir toplumsal rol için gerek duyulan bilgi, beceri ve tutumların düzeyini anlatır. Bu kavramın bireysel anlamdaki karşılığı ise özyeterliktir (Yeşilyurt, 2013). Sosyal Bilişsel Kuram'a göre bireylerin özyeterlik algıları, yaptıkları eylemlerin arkasında yatan temel güdüsel yapıdır (Kurt, 2012). Hem eğitim hem de yönetim bilimi yazınında, farklı işlevler için tanımlanmış çeşitli yeterlik ve özyeterlik türleri vardır. Bunlardan en yaygın olanlarının mesleki yeterlik, kolektif yeterlik, matematiksel özyeterlik, akademik özyeterlik ve öğretmen özyeterliği olduğu söylenebilir (Uysal, 2013). Bireylerin özyeterlik algıları, belli bir konuda hedeflenen sonuçlara ulaşılmasını sağlayacak belli davranışların gerçekleştirilebilmesine ilişkin kişisel değerlendirmeleri ifade ettiğinden (Bieschke, 2006), aslında öznel bir algıyı işaret eder. Türkiye'deki eğitim alanyazınında henüz çok yeni olan yaşamboyu öğrenme yeterliği de, özyeterlik algısına paralel beceriler ve bunlara ilişkin kişisel değerlendirmelerden oluşur.

"Yaşamboyu öğrenme becerileri" kavramı ise, bireyin yaşamı süresince, kendini gerçekleştirmesi ve mesleğini sürdürebilmesi için gereken temel becerileri kapsamakta olup, bilişsel, duyuşsal ve devinişsel becerileri ifade eder (Coşkun \& Demirel, 2012; Konokman \& Yelken, 2014). Bu becerilerden oluşan yeterlik profilinde, farkl yaklaşımlardan farklı öğeler olduğu söylenebilir. Örneğin, alanyazındaki temel beceriler 
ve özellikler arasında sürekli biçimde öğrenme isteğine sahip olma, kendi öğrenme etkinliklerine ilişkin sorumluluğu alma, öğrenmeyi öğrenme, kavrayarak okuma, temel sözel ve sayısal beceriler, kendini geliştirme yeteneği, bilgi teknolojilerini kullanma becerisi, problem çözme ve eleştirel düşünme becerilerine sahip olma, öz-düzenleyici öğrenme becerisi ve araştırma becerileri yer alır (Coşkun \& Demirel, 2012). Avrupa Komisyonu'nun kabul ettiği beceriler olarak ana dilde ve yabancı dilde iletişim, matematiksel düşünme, bilim ve teknolojide temel beceriler, dijital araçları kullanma, öğrenmeyi öğrenme, sosyal yurttaş olma bilinci ve girişimcilik ile kültürel bilinç ve ifade yeterlikleri bulunmaktadır (Konokman \& Yelken, 2014; Otten \& Ohana, 2009). Nitekim, Avrupa Birliği' ndeki ve dünyadaki tüm eğitim araştırmalarında temel referans haline gelen bu sekiz temel beceri, yaşamboyu öğrenme yeterliği kavramının da çekirdeğini oluşturmuştur.

Yaşamboyu öğrenme yeterliklerine ilişkin dünyadaki bazı temel araştırma ve raporlarda da, bireysel beceriler benzer sınıflandırmalarla tanımlanmıştır. Örneğin, bu çalışmaları büyük oranda etkilemiş olan OECD-PISA uygulamalarının temelinde, öğrencilerin yaşamboyu öğrenme ihtiyaçlarını algılayıp eyleme geçmesini sağlayan temel beceriler ve yeterlikler yer almaktadir. Bu yeterlikler, DeSeCo Projesi'nde (Definition and Selection of Key Competencies) tanımlanmış olup, hem başarılı bir bireysel yaşam hem de kurumları ve işlevleriyle sağlıklı işleyen bir toplum için kilit rol oynayan temel yeterlikler olarak çeşitli araçları interaktif olarak kullanabilmek (dil, semboller,...vb.), heterojen bir grup içinde karşılıklı iletişim kurabilmek ve bağımsız olarak hareket edebilmek, tanımlanmıştır (OECD, 2005).

Birbirleriyle bağlantılı bu geniş kapsamlı yeterlik alanları, birçok araştırmanın ve yeterlikle ilgili çalışmaların temelini oluşturmuştur. Bu bağlamda, mühendislik meslek alanı için yapılmış bir çalışmada, üç temel yeterlik grubu mühendislik mesleğine uyarlanmış ve mühendislerin yaşamboyu öğrenmeye ilişkin yeterlikleri ve yaklaşımları değerlendirilmiştir. Elektrik ve makine mühendisliği öğrencilerine uygulanan kurs programı sonunda, öğrencilerin çoğunluğunun yaşamboyu öğrenmeye ilişkin algılarının yüksek olduğu ve yaşamboyu öğrenme yeterliklerinin kurs sonunda artış sergilediği gözlenmiştir (Martinez-Mediano \& Lord, 2012). Kütüphane görevlilerine dönük olarak Hırvatistan' da yapılmış bir araştırmada, "konuya özgü mesleki yeterlikler" ve "genel yeterlikler" olmak üzere, iki tür yeterlik alanı tanımlanmıştır. Genel yeterliklerde yer alan beceriler, yukarıda belirtilen üç ana yeterlik alanına paralel becerileri içermekte olup, bu beceriler, katılımcıların en yüksek değerleri sergilediği alan olmuştur (Machala \& Horvat, 2010).

Türkiye'deki yaşamboyu öğrenme ve ilgili yeterliklere ilişkin araştırmalara bakıldığında öğretmenler, akademisyenler ve öğrenciler üzerine yapılmış çalışmalar karşımıza çıkmaktadır. Bu alandaki son çalışmalardan biri, Konokman ve Yelken (2014)' in çalışmasıdır. Türkiye'deki 8 üniversiteden eğitim fakültelerinin öğretim elemanlarına uygulanmış olan bu çalışmada, hem yaşamboyu öğrenme yeterlik ölçeği geliştirilmiş hem de eğitim fakültesi öğretim elemanlarının yüksek düzeyde bir yaşamboyu öğrenme yeterlik algısına sahip olduğu görülmüştür. $\mathrm{Bu}$ profile göre 
cinsiyet, yabancı dil seviyesi ve teknoloji kullanma becerisi bu algıda etkili olup, kadın öğretim elemanları ile yabancı dil seviyesi ve teknolojiyi kullanma düzeyi yüksek olanlar, diğerlerine göre daha yüksek bir yaşamboyu öğrenme yeterlik algısı taşımaktadır (Konokman \& Yelken, 2014). Bu çalışmada kullanılmış olan ölçeğin geliştirildiği araştırma ise, Uzunboylu ve Hürsen'in (2011) çalışmasıdır. Tesadüfi olarak seçilmiş okullarda görev yapan 300 öğretmene uygulanan çalışmada, 6 alt boyuttan ve 51 maddeden oluşan bir yaşamboyu öğrenme yeterlik ölçeği geliştirilmiştir (Uzunboylu \& Hürsen, 2011). Coşkun ve Demirel (2012)'in üniversite öğrencilerinin yaşamboyu öğrenme eğilimlerine ilişkin araştırmasında, öğrencilerin yaşamboyu öğrenme eğilimlerinin üniversitelerine, sınıf düzeyine ve cinsiyete göre değişimi incelenmiştir. Bulgulara göre, üniversite öğrencilerinin yaşamboyu öğrenme eğilimleri düşük çıkmış; bu eğilimin örgün eğitimdeki sınıf düzeyine göre pek fazla değişmediği ve kız öğrencilerin yaşamboyu öğrenme eğiliminin daha yüksek olduğu saptanmıştır (Coşkun \& Demirel, 2012).

Karakuş (2013)'un meslek yüksekokulu öğrencilerini kapsayan çalışmasında, öğrencilerin yaşamboyu öğrenme yeterlik puanları iyi düzeyde çıkmıştır. Alt boyutlarda anadilde iletişim ile sosyal-vatandaşlık yeterlikleri düzeyleri oldukça iyi düzeyde olup, öğrencilerin bölümleri ile yeterlik düzeyleri arasında anlamlı bir farklılık bulunmamıştır (Karakuş, 2013). Şahin ve Arcagök (2014)'ün ilköğretim okullarında görev yapan öğretmenlere dönük araştırmasında, öğretmenlerin genel özyeterlik düzeyi yüksek, fakat, karar verebilmeye ilişkin alt boyut yeterlik düzeyleri diğer yeterliklerine kıyasla daha düşük bulunmuştur. Buna ek olarak, kadın ve erkek öğretmenlerin yeterliklerinin birbirine çok yakın olduğu ve bilgiyi elde etme ile dijital yeterlik boyutlarındaki yeterliklerin, öğretmenlerin öğrenim durumu ve mesleki kıdem düzeyine göre anlamlı farklılıklar gösterdiği ortaya çıkmıştır (Şahin \& Arcagök, 2014). Selvi'nin 2007 yılındaki araştırmasında, İngilizce öğretmenlerinin yaşamboyu öğrenme yeterlikleri değerlendirilmiştir. Bu çalışma bulgularına göre, öğretmenlerin yaşamboyu öğrenme yeterliklerinin, kendileriyle ve öğrencilerin yaşamboyu öğrenme becerileriyle ilgili olmak üzere iki alt boyuttan oluştuğu ve yaşamboyu öğrenme becerileri yeterli olmayan öğretmenlerin öğrencilerinin de uygun düzeyde yaşamboyu öğrenme becerilerine sahip olmayabileceği öngörülmüştür (Selvi, 2011). Çelikkaleli (2011)'nin Mersin Halk Eğitimi Merkezi'nde ders veren öğretmenlere yönelik çalışması ise, öğretmenlerin tükenmişlik düzeyleri ile mesleki yetkinlik algısını ele almıştır. Bu araştırmada, öğretmenlerin yetkinlik inançları ile cinsiyetleri, öğrenci sayıları ve yüksek eğitimlerinin türü (lisans veya ön-lisans) arasında anlamlı bir ilişki bulunamamıştır. Bu nedenle, yetkinlik algısının belirleyen başka etkenlerin söz konusu olduğu söylenebilir (Çelikkaleli, 2011). Sonuç olarak, günümüz küresel rekabet dünyasında, yaşamboyu öğrenme olgusuyla birlikte, kişisel becerilerin sürekli olarak geliştirilmesi ve bireysel yeterliklerin artırılması gerekliliği önem kazanmıştır. Yaşamboyu öğrenme yeterlikleri, bu düzlemdeki ölçme araçlarından biri olarak değerlendirilmeli ve hangi etkenlerle biçimlendikleri izlenmelidir. 


\section{Yöntem}

$\mathrm{Bu}$ çalışma kapsamında, 2015 y1lı bahar döneminde, Mersin'in Erdemli ve Mezitli ilçelerindeki halk eğitimi merkezlerinde görev yapan öğretmenlere ve usta öğreticilere Yaşam Boyu Öğrenme Yeterlikleri Ölçeği uygulanmıştır. Fakat, çalışma, bir ölçeğin anket formu olarak uygulanmasından ibaret değildir. Erdemli HEM'de eğitici olarak görev yapanlara dönük yirmi saatten oluşan seminer programı kapsamında uygulanmıştır. $\mathrm{Bu}$ programda, seminerlere başlamadan önce Yaşamboyu Öğrenme Yeterlikleri Ölçeği uygulanmıştır. Mezitli HEM'de görev yapanlara ise, ölçek uygulamasını takiben, "Halk Eğitiminde Yetişkin Eğitimi İlkelerinin Uygulanması" konulu 2 saatlik bir seminer uygulaması yapılmıştır. Ölçek anketi uygulaması, halk eğitimi merkezleri müdürlüklerinin çağrısına uyarak seminere katılmak üzere gelmiş olan eğiticiler üzerinde gerçekleştirilmiştir. Katılımcıların büyük çoğunluğu, bayanlardan oluşmaktadır. Dolayısıyla, çalışmanın bulguları, Mart-Nisan 2015 döneminde, Mersin ilindeki Erdemli ve Mezitli halk eğitimi merkezlerinde erişilebilen eğitim personeliyle sınırlıdır.

$\mathrm{Bu}$ çalışma, betimsel bir araştırmadır. Araştırmanın odağındaki veya hedefindeki bir olguyu veya nesneyi inceleyerek mevcut durumunun ortaya konulmasinı ifade eden betimsel araştırma (Altunışık, Coşkun, Bayraktaroğlu \& Yıldırım, 2010) modeli, eğitim araştırmalarında da yaygın biçimde tercih edilmektedir. Araştırmada, halk eğitimi merkezlerinde görev yapan eğiticilerin yaşamboyu öğrenme yeterlikleri algısının bazı bireysel değişkenlere göre değişiminin betimlenmesi hedeflenmiştir.

\section{Evren ve Örneklem}

Çalışmanın araştırma evreni, Mersin ilinde Milli Eğitim Bakanlığı'na bağlı olarak faaliyet gösteren halk eğitimi merkezlerinde görev yapmakta olan öğretmenler ile kadrolu ve sözleşmeli usta ögreticilerdir. Mersin'in Erdemli ve Mezitli ilçelerindeki Halk Eğitimi Merkezi müdürlüklerinde görev yapan eğitim personelinden, tesadüfi örneklem yoluyla ulaş1labilmiş olan 121 kadrolu ve kadrosuz usta öğretici ve öğretmen, bu araştırmanın çalışma grubunu oluşturmuştur.

\section{Veri Toplama Aracı}

Bu araştırmada, Uzunboylu ve Hürsen'(2011)'in, AB'nin işaret ettiği 8 temel yeterlik çerçevesinde geliştirmiş olduğu Yaşamboyu Öğrenme Yeterlik Ölçeği ve demografik profil soru dizisi birlikte kullanılmıştır. Demografik profil kısmında 6 soru yer almakta; yeterlikler ölçeği ise 6 alt boyut ve 51 maddeden oluşmaktadır. Ölçekte, Likert tipi derecelendirme yapılmış olup Hiç-1, Az-2, Orta-3, Çok-4 ve Tam-5 olarak düzenlenmiştir. Uzunboylu ve Hürsen, ölçeğin toplam güvenirlik katsayısını 0.95 olarak, alt boyutlarının güvenirlik değerlerini (cronbach alfa katsayısı) ise sırasıyla özyönetim yeterlikleri 0.93 ; öğrenmeyi öğrenme yeterlikleri 0.91 ; inisiyatif ve girişimcilik yeterlikleri 0.89 ; bilgili elde etme yeterliği 0.83 ; dijital yeterlikler 0.85 ve karar verebilme yeterlikleri için 0.75 olarak belirtmiştir (Uzunboylu \& Hürsen, 2011). Ölçek alt boyutlarının madde sayıları ise şöyledir: Özyönetim yeterlikleri 13 madde; öğrenmeyi öğrenme yeterlikleri 12 madde; inisiyatif ve girişimcilik yeterlikleri 10 
madde; bilgiyi elde etme yeterliği 6 madde; dijital yeterlikler 6 madde ve karar verebilme yeterliği 4 maddeden oluşmaktadır.

Ölçeğin uygulanması, her iki kurumdaki seminer uygulamalarından önce toplu olarak yapılmıştır. Böylece, hem genel açıklamaların yapılması hem de katılımcıların anket formuyla ilgili yönelttiği soruların yanıtlanması mümkün olmuştur.

\section{Veri Analizi}

Araştırma bulgularının analizinde, SPSS (Statistical Package for Social Sciences) for Windows 22.0 programı kullanılmıştır. Verilerin değerlendirilmesinde betimsel/tanımlayıcı istatistiksel yöntemler olarak sıklık, yüzde, ortalama ve standart sapma kullanılmıştır. İki bağımsız grup arasındaki niceliksel sürekli verilerin karşılaştırılmasında Man Whitney-U Testi, ikiden fazla bağımsız grup arasında niceliksel sürekli verilerin karşılaştırılmasında ise Kruskall Whallis testi kullanılmıştır. Kruskall Whallis testi sonrasında, farklılıkları belirlemek üzere tamamlayıcı olarak, Man Whitney-U Testi uygulanmıştır. Elde edilen bulgular \%95 güven aralığında ve \%5 anlamlılık düzeyinde değerlendirilmiştir.

\section{Bulgular}

$\mathrm{Bu}$ kısımda, öncelikle, katılımcılara uygulanmış olan ölçeğin genel ve alt boyutlarına ilişkin güvenirlik bulguları sunulmuştur. Daha sonra sırasıyla, katılımcıların demografik profili, ölçeğin alt boyutları ve araştırma amaçlarıyla ilgili bulgular aktarılmıştır.

Tablo 1

Genel Ölçek ve Alt Boyutların Güvenirlik Değerleri

\begin{tabular}{lcc}
\hline & $\begin{array}{c}\text { Madde } \\
\text { Sayısı }\end{array}$ & $\begin{array}{c}\text { Cronbach } \\
\text { Alpha Değeri }\end{array}$ \\
\hline Genel & 51 & 0.966 \\
Özyönetim Yeterlikleri & 13 & 0.860 \\
Öğrenmeyi Ö̆ğrenme Yeterlikleri & 12 & 0.903 \\
İnisiyatif ve Girişimcilik Yeterlikleri & 10 & 0.908 \\
Bilgiyi Elde Etme Yeterliği & 6 & 0.834 \\
Dijital Yeterlikler & 6 & 0.945 \\
Karar Verebilme Yeterliği & 4 & 0.869
\end{tabular}

Tablo 1'de görüldüğü gibi, ölçeğin hem genel hem de alt boyutlardaki faktörler açısından güvenirlik değerleri yüksek bulunmuştur. 


\section{Demografik Profil, Mesleki Alan ve Seminer Deneyimi Bulguları}

$\mathrm{Bu}$ kısımda, çalışma grubundaki eğitim personelinin demografik profili, ders verdikleri mesleki alanları ile daha önceden bir seminere katılma deneyiminin dağılımına yer verilmiştir.

Tablo 2

Demografik Profil

\begin{tabular}{|c|c|c|c|}
\hline & & $f$ & $\%$ \\
\hline \multirow{3}{*}{ Cinsiyet } & Kadın & 111 & 91.7 \\
\hline & Erkek & 10 & 8.3 \\
\hline & Toplam & 121 & 100 \\
\hline \multirow{7}{*}{ Yaş } & 30 ve alt 1 & 13 & 10.7 \\
\hline & $31-35$ & 13 & 10.7 \\
\hline & $36-40$ & 23 & 19 \\
\hline & $41-45$ & 27 & 22.3 \\
\hline & $46-50$ & 30 & 24.8 \\
\hline & 50 üzeri & 15 & 12.4 \\
\hline & Toplam & 121 & 100 \\
\hline \multirow{5}{*}{ Eğitim Durumu } & Lise ve alt 1 & 71 & 58.7 \\
\hline & Ön Lisans & 24 & 19.8 \\
\hline & Lisans & 23 & 19 \\
\hline & Lisansüstü & 3 & 2.5 \\
\hline & Toplam & 121 & 100 \\
\hline \multirow{6}{*}{ Deneyim } & 1 yildan az & 15 & 12.4 \\
\hline & $1-5$ y1l & 39 & 32.2 \\
\hline & $6-10$ y1l & 30 & 24.8 \\
\hline & $11-15$ y1l & 11 & 9.1 \\
\hline & 15 yıldan fazla & 26 & 21.5 \\
\hline & Toplam & 121 & 100 \\
\hline
\end{tabular}

Tablo 2'de görüldügü gibi, katılımcıların 111'i (\%91.7) kadın ve 10'u (\%8.3) erkektir. Bu durum, Türkiye'deki halk eğitim merkezlerinin eğitim personelinin, ağırlıklı olarak kadın eğiticilerden oluşmasından kaynaklanabilir. Katılımcıların yaş değişkenine göre, 13'ü (\%10.7) 30 ve altı, 13'ü (\%10.7) 31-35, 23'ü (\%19) 36-40, 27'si (\%22.3) 41-45, 30'u (\%24.8) 46-50 ve 15'i (\%12.4) 50 üzeri yaştadır. Eğitim 
değişkenine göre bakıldığında, katılımcıların 71'i (\%58.7) lise ve altı, 24'ü (\%19.8) ön lisans ve 26'sı (\%21.5) lisans ve üstü düzeyde eğitime sahiptir. Bu durum, katılımcıların eğitim düzeyinin, ağırlıklı olarak lise ve altı düzeyinde olduğunu göstermektedir. Katılımcıların mesleki deneyim değişkenine göre bakıldığında, 15'i (\%12.4) 1 yıldan az, 39'u (\%32.2) 1-5 y1l, 30'u (\%24.8) 6-10 yıl, 11'i (\%9.1) 11-15 y11, 26's1 (\%21.5) 15 yıldan fazla deneyimli olduğu görülmektedir. Bu bulgular 1şığında, çalışma grubunun, çoğunluğu kadın olan, eğitim düzeyi düşük, az deneyimli ve orta yaşlı bir kitleden oluştuğu görülmüştür.

Tablo 3

Mesleki Alanlar

\begin{tabular}{lcc}
\hline & $f$ & $\%$ \\
\hline El sanatları & 36 & 29.8 \\
Dekoratif ev tekstili/mefruşat & 11 & 9.1 \\
Giyim-konfeksiyon teknolojileri & 10 & 8.3 \\
Makine nakışları & 9 & 7.4 \\
Resim & 9 & 7.4 \\
Spor * & 8 & 6.6 \\
Kuaförlük & 7 & 5.8 \\
Dikiş ve el nakışı & 6 & 5 \\
Ahşap süsleme & 5 & 4.1 \\
Hasta bakımı ve yaşlı hizmetleri & 4 & 3.3 \\
Bahçecilik & 3 & 2.5 \\
Bilgisayar & 3 & 2.5 \\
Çocuk gelişimi & 2 & 1.7 \\
Diğer ** & 8 & 6.4 \\
Toplam & 121 & 100 \\
\hline
\end{tabular}

* Bu grupta tekvando, kikboks, karate, step ve aerobik bulunmaktadır.

** Bu gruptaki ders alanları takı tasarım, ebru-tezhip, bilgisayarlı muhasebe, yiyecek-içecek hizmetleri, arıcılık, cilt bakımı, cam-seramik ve halk oyunları olup, her birinde birer öğretici bulunmaktadır.

Tablo 3'de yer alan bulgulara göre, araştırmaya katılanların yaklaşık üçte biri, el sanatları odaklı dersler yürütmektedir. Alanların dağılımına ve içeriğine bakıldığında ise, büyük bölümünün birbirine yakın ve paralel konuları kapsadığı ve bu nedenle daha çok kadınlara yönelik el becerilerini kapsayan (dekoratif ev tekstili, giyim-konfeksiyon, makine ve el nakışı) bir profil olduğu anlaşılmaktadır. Nitekim bu durum, Türkiye genelindeki halk eğitimi merkezlerinin ders içeriklerinin ve öğrenci profillerinin durumunu yansitmaktadir. 
Tablo 4 ise, çalışma grubunu oluşturan eğiticilerin, daha önce bir mesleki seminere katılım deneyimlerine ilişkin bulguları göstermektedir.

Tablo 4

Bir Seminere Katılma Deneyimi

\begin{tabular}{lcc}
\hline & $f$ & $\%$ \\
\hline Daha önce başka bir seminere katılmış olanlar & 79 & 65.3 \\
Daha önce başka bir seminere katılmamış olanlar & 42 & 34.7 \\
Toplam & 121 & 100
\end{tabular}

Çalışma grubundakilerin \%34.7'si, görevleriyle ilgili olarak daha önce hiçbir eğitim seminerine katılmadıklarını beyan etmiştir. Tablo 4'deki bulgulara göre, katılımcıların \%65.3'ü en az bir eğitim semineri deneyimi yaşamıştır.

\section{Araştırma Amaçlarına Yönelik Bulgular}

$\mathrm{Bu}$ kısımda, çalışma grubundaki eğiticilerin yaşamboyu yeterlik düzeyi algıları ile yaş, cinsiyet, eğitim düzeyi ve deneyim değişkenleri arasındaki ilişkiye dair bulgulara yer verilmiştir.

Halk eğitim merkezinde görev yapan eğiticilerin yaşamboyu öğrenme yeterlik düzeyi algısı. Araştırma bulgularına göre, katılımcıların yaşamboyu öğrenme yeterlik düzeyleri, hem alt boyutlarda hem de genel yeterlik düzleminde çok yüksek bulunmuştur. Bunun geçerli olmadığı tek alt boyut, "dijital yeterlikler" olmuştur. Tablo 5, katılımcıların yaşamboyu öğrenme yeterliklerinin ortalama puanları ile standart sapma değerlerini göstermektedir.

Tablo 5

Yaşamboyu Öğrenme Yeterlik Düzeyleri

\begin{tabular}{lccc}
\hline & $n$ & Ort. & $s s$ \\
\hline Özyönetim & 121 & 4.238 & 0.520 \\
Öğrenmeyi öğrenme & 121 & 4.293 & 0.555 \\
İnisiyatif ve girişimcilik & 121 & 4.373 & 0.559 \\
Bilgiyi elde etme & 121 & 4.113 & 0.775 \\
Dijital & 121 & 3.880 & 1.080 \\
Karar verebilme & 121 & 4.176 & 0.700 \\
Genel & 121 & 4.219 & 0.543 \\
\hline
\end{tabular}

Tablo 5'den görüldüğü üzere, katılımcıların “özyönetim yeterlikleri” düzeyi çok yüksek; "öğrenmeyi öğrenme yeterlikleri” düzeyi çok yüksek; "inisiyatif ve girişimcilik 
yeterlikleri" düzeyi çok yüksek; "bilgiyi elde etme yeterliği” düzeyi yüksek; "dijital yeterlikler" düzeyi yüksek; "karar verebilme yeterliği” düzeyi yüksek ve "genel yaşamboyu öğrenme yeterlikler” düzeyi de çok yüksek olarak saptanmıştır. Öğrenmeyi öğrenme ile inisiyatif ve girişimcilik yeterlikleri, diğer yeterliklere göre daha yüksek bulunmuştur.

Halk eğitim merkezinde görev yapan eğiticilerin yaşamboyu öğrenme yeterlikleri algısının, yaş ve cinsiyet değişkenlerine göre durumu. Araştırmaya katılan çalışanların özyönetim yeterlikleri, öğrenmeyi öğrenme yeterlikleri, inisiyatif ve girişimcilik yeterlikleri puan ortalamalarının yaş değişkeni açısından grup ortalamaları arasındaki fark anlamlı bulunmamıştır $(p>0.05)$. Buna karşılık, katılımcıların yaşı ile bilgiyi elde etme yeterliği, dijital yeterlikler, karar verebilme yeterliği ve genel yeterlikler ortalamaları arasında anlamlı farklılık olduğu görülmüştür. Tablo 6, anlamlı bulunan yeterliklerin yaşa göre ortalamalarını, standart sapmalarını ve test sonuçlarını göstermektedir.

Araştırmaya katılan eğiticilerin "bilgiyi elde etme" yeterliği puanları ortalamalarının yaş değişkeni açısından anlamlı bir farklılık gösterdiği görülmüştür $(\mathrm{KW}=14.846 ; p=0.011<0.05)$. Tablo-6'da görüldüğü gibi, yaşı 30 ve altı olanların bilgiyi elde etme yeterliği puanları, diğer grupların tümünden daha yüksek çıkmıştır. Yaşı 31-35 olanların bilgiyi elde etme yeterliği puanları, yaşı 46-50 olanların bilgiyi elde etme yeterliği puanlarından yüksek bulunmuştur. Yaşı 36-40 olanların bilgiyi elde etme yeterliği puanları ise, yaşı 46-50 olanların bilgiyi elde etme yeterliği puanlarından yüksek bulunmuştur. Araştırmaya katılan çalışanların "dijital yeterlikler" puanları ortalamalarının yaş değişkeni açısından anlamlı bir farklılık gösterip göstermediğini belirlemek amacıyla yapılan Kruskal Wallis H-Testi sonuçlarına göre; grup ortalamaları arasındaki fark anlamlı bulunmuştur $(\mathrm{KW}=27.541 ; p=0.000<0.05)$. Yaş1 30 ve altı olanların dijital yeterlikler puanları $(4.577 \pm 0.949)$, diğer tüm yaş gruplarından daha yüksek çıkmıştır. 
Tablo 6

Yaşamboyu Öğrenme Yeterliklerinin Yaş Değişkenine Göre Durumu

\begin{tabular}{|c|c|c|c|c|c|c|}
\hline & Yaş Grup & $n$ & Ort. & ss & $K W$ & $p$ \\
\hline \multirow{6}{*}{$\begin{array}{l}\text { Bilgiyi Elde Etme } \\
\text { Yeterliği }\end{array}$} & 30 ve alt 1 & 13 & 4.526 & 0.604 & \multirow{6}{*}{14.846} & \multirow{6}{*}{0.011} \\
\hline & $31-35$ & 13 & 4.41 & 0.576 & & \\
\hline & $36-40$ & 23 & 4.362 & 0.705 & & \\
\hline & $41-45$ & 27 & 3.969 & 0.89 & & \\
\hline & $46-50$ & 30 & 3.783 & 0.757 & & \\
\hline & $50+$ & 15 & 4.033 & 0.699 & & \\
\hline \multirow{6}{*}{ Dijital Yeterlikler } & 30 ve alt 1 & 13 & 4.577 & 0.949 & \multirow{6}{*}{27.541} & \multirow{6}{*}{0.000} \\
\hline & $31-35$ & 13 & 4.539 & 0.605 & & \\
\hline & $36-40$ & 23 & 4.109 & 1.026 & & \\
\hline & $41-45$ & 27 & 3.796 & 1.063 & & \\
\hline & $46-50$ & 30 & 3.217 & 0.98 & & \\
\hline & $50+$ & 15 & 3.833 & 1.13 & & \\
\hline \multirow{6}{*}{$\begin{array}{l}\text { Karar Verebilme } \\
\text { Yeterliği }\end{array}$} & 30 ve alt 1 & 13 & 4.346 & 0.704 & \multirow{6}{*}{12.308} & \multirow{6}{*}{0.031} \\
\hline & $31-35$ & 13 & 4.577 & 0.426 & & \\
\hline & $36-40$ & 23 & 4.239 & 0.596 & & \\
\hline & $41-45$ & 27 & 4.204 & 0.757 & & \\
\hline & $46-50$ & 30 & 3.833 & 0.794 & & \\
\hline & $50+$ & 15 & 4.217 & 0.508 & & \\
\hline \multirow{6}{*}{$\begin{array}{l}\text { Genel Yaşamboyu } \\
\text { Öğrenme } \\
\text { Yeterlikleri }\end{array}$} & 30 ve alt 1 & 13 & 4.389 & 0.559 & \multirow{6}{*}{12.547} & \multirow{6}{*}{0.028} \\
\hline & $31-35$ & 13 & 4.477 & 0.337 & & \\
\hline & $36-40$ & 23 & 4.304 & 0.519 & & \\
\hline & $41-45$ & 27 & 4.2 & 0.606 & & \\
\hline & $46-50$ & 30 & 3.969 & 0.544 & & \\
\hline & $50+$ & 15 & 4.25 & 0.461 & & \\
\hline
\end{tabular}

Katılımcıların "karar verebilme" yeterliği puanı ortalamalarının arasında, yaş değişkeni açısından anlamlı bir fark bulunmuştur $(\mathrm{KW}=12.308 ; p=0.031<0.05)$. Buna göre, yaşı 30 ve altı olanların karar verebilme yeterliği puanları, yaşı 46-50 olanların karar verebilme yeterliği puanlarından, yaşı 31-35 olanların karar verebilme yeterliği puanları, yaşı 46-50 olanların karar verebilme yeterliği puanlarından daha yüksektir. Araştırmaya katılan çalışanların "genel yaşamboyu öğrenme yeterlikleri" puanları ortalamalarının yaş değişkeni açısından anlamlı bir farklılık gösterip göstermediğini 
belirlemek amacıyla yapılan Kruskal Wallis H-Testi sonuçlarına göre, grup ortalamaları arasındaki fark da anlamlı bulunmuştur $(\mathrm{KW}=12.547 ; p=0.028<0.05)$. Farklılı̆̆ın hangi gruptan kaynaklandığını belirlemek üzere Mann Whitney U testi uygulanmış olup, yaşı 30 ve altı olanların genel yaşamboyu öğrenme yeterlikler puanları, yaşı 46-50 olanların genel yaşamboyu öğrenme yeterlikler puanlarından yüksek bulunmuştur. Yaşı 31-35 olanların genel yaşamboyu öğrenme yeterlikler puanları ise, yaşı 46-50 olanların puanlarından yüksektir. Bu bulgulara dayanarak, 36 yaş altındaki eğiticilerin bilgiyi elde etme, dijital, karar verebilme ve genel yaşamboyu öğrenme yeterliklerinin diğer yaş gruplarına kıyasla daha yüksek olduğu söylenebilir.

Tablo 7, çalışma grubundaki eğiticilerin, cinsiyetlerine göre yaşamboyu öğrenme yeterlikler düzeylerinin ortalama, standart sapma ve test değerlerinin dağılımını göstermektedir.

Tablo 7

Yaşamboyu Öğrenme Yeterliklerinin Cinsiyete Göre Durumu

\begin{tabular}{|c|c|c|c|c|c|c|}
\hline & Yaş Grup & $n$ & Ort. & ss & $M W$ & $p$ \\
\hline \multirow{2}{*}{$\begin{array}{l}\text { Özyönetim } \\
\text { Yeterlikleri }\end{array}$} & Kadın & 111 & 4.219 & 0.515 & \multirow{2}{*}{401} & \multirow{2}{*}{0.146} \\
\hline & Erkek & 10 & 4.444 & 0.557 & & \\
\hline \multirow{2}{*}{$\begin{array}{l}\text { Öğrenmeyi } \\
\text { Öğrenme } \\
\text { Yeterlikleri }\end{array}$} & Kadın & 111 & 4.279 & 0.55 & \multirow{2}{*}{424.5} & \multirow{2}{*}{0.218} \\
\hline & Erkek & 10 & 4.45 & 0.615 & & \\
\hline \multirow{3}{*}{$\begin{array}{l}\text { İnisiyatif ve } \\
\text { Girişimcilik } \\
\text { Yeterlikleri }\end{array}$} & Kadın & 111 & 4.377 & 0.553 & \multirow{3}{*}{542.5} & \multirow{3}{*}{0.906} \\
\hline & & & & & & \\
\hline & Erkek & 10 & 4.322 & 0.651 & & \\
\hline \multirow{2}{*}{$\begin{array}{l}\text { Bilgiyi Elde Etme } \\
\text { Yeterliği }\end{array}$} & Kadın & 111 & 4.132 & 0.746 & \multirow{2}{*}{522.5} & \multirow{2}{*}{0.758} \\
\hline & Erkek & 10 & 3.9 & 1.069 & & \\
\hline \multirow{2}{*}{ Dijital Yeterlikler } & Kadın & 111 & 3.889 & 1.068 & \multirow{2}{*}{542.5} & \multirow{2}{*}{0.905} \\
\hline & Erkek & 10 & 3.783 & 1.265 & & \\
\hline \multirow{2}{*}{$\begin{array}{l}\text { Karar Verebilme } \\
\text { Yeterliği }\end{array}$} & Kadın & 111 & 4.164 & 0.7 & \multirow{2}{*}{470} & \multirow{2}{*}{0.417} \\
\hline & Erkek & 10 & 4.3 & 0.725 & & \\
\hline \multirow{3}{*}{$\begin{array}{l}\text { Genel Yaşamboyu } \\
\text { Öğrenme } \\
\text { Yeterlikleri }\end{array}$} & Kadın & 111 & 4.215 & 0.533 & \multirow{3}{*}{495.5} & \multirow{3}{*}{0.575} \\
\hline & & & & & & \\
\hline & Erkek & 10 & 4.259 & 0.676 & & \\
\hline
\end{tabular}

Tablo 7'deki bulgulardan görüldüğü gibi, eğiticilerin yaşamboyu öğrenme yeterlikleri alt boyutları ve genel yaşamboyu öğrenme yeterlikleri düzeylerinin puan ortalamalarının cinsiyet değişkenine göre anlamlı bir farklılık gösterip göstermediğini belirlemek amacıyla Mann Whitney-U testi uygulanmış olup, grup ortalamaları 
arasındaki fark istatistiksel açıdan anlamlı bulunmamıştır $(p>0.05)$. Bunun, eğiticilerin büyük bölümünün kadınlardan oluşmasından kaynaklandığı düşünülmektedir.

\section{Halk eğitim merkezinde görev yapan eğiticilerin yaşamboyu öğrenme yeterlikleri algısının, mesleklerindeki deneyim süresine göre durumu.}

Araştırma bulgularına göre, çalışma grubundaki eğiticilerin genel yaşamboyu öğrenme yeterlikleri, özyönetim, öğrenmeyi öğrenme, inisiyatif ve girişimcilik ile karar verebilme yeterlikleri puan ortalamaları, mesleki deneyim açısından anlamlı bir farklılık göstermemektedir. Katılımcıların "bilgiyi elde etme" ve "dijital" yeterliklerinin puan ortalamaları ise, Kruskal Wallis H-Testi sonuçlarına göre anlamlı farklılık sergilemektedir. Tablo 8, bilgiyi elde etme ve dijital yeterliklerin ortalamalarını göstermektedir.

Tablo 8'deki bulgulara göre, eğiticilerin "bilgiyi elde etme" yeterliği ve "dijital" yeterliklerinin ortalama puanları ile deneyim değişkeni arasında anlamlı bir farklılık mevcuttur $(\mathrm{KW}=9.788 ; p=0.044<0.05)$. Bilgiyi elde etme yeterliğinde, farklılığın hangi gruptan kaynaklandığını belirlemek üzere Mann Whitney U-testi uygulanmıştır. Buna göre, deneyimi 1-5 yıl olanların bilgiyi elde etme yeterliği puanları, deneyimi 15 yıldan fazla olanların bilgiyi elde etme yeterliği puanlarından yüksek çıkmıştır. Katılımcıların "dijital yeterlikler" puanları ortalamalarının deneyim değişkeni açısından grup ortalamaları arasındaki fark da anlamlı bulunmuştur $(\mathrm{KW}=11.333 ; p=0.023<0.05)$. Deneyimi 1-5 yıl olanların dijital yeterlikler puanları, deneyimi 15 yıldan fazla olanların dijital yeterlikler puanlarından, deneyimi 6-10 yıl olanların dijital yeterlikler puanları ise, deneyimi 15 yıldan fazla olanların puanlarından daha yüksek olduğu görülmüştür. Sonuç olarak, mesleki deneyimi 1-5 yıl arasında olan eğiticilerin, her iki yeterlik alanında da diğer gruplardan daha yüksek bir yeterlik algısına sahip olduğu görülmektedir. Dolayısıyla, eğiticilerin bilgiyi elde etme ve dijital yeterliklerinin, öğreticilik deneyiminin artışıyla birlikte artmadığı söylenebilir.

Tablo 8

Yaşamboyu Öğrenme Yeterlikleri Düzeylerinin Mesleki Deneyime Göre Durumu

\begin{tabular}{llccccc}
\hline \multicolumn{1}{c}{ Yaş Grup } & $n$ & Ort. & ss & KW & $p$ \\
\hline & 1 y1ldan az & 15 & 3.978 & 0.615 & & \\
Özyönetim & $1-5$ y1l & 39 & 4.305 & 0.454 & & \\
Yeterlikleri & $6-10$ y1l & 30 & 4.315 & 0.489 & 5.389 & 0.250 \\
& $11-15$ yıl & 11 & 4.394 & 0.396 & & \\
& 15 y1l + & 26 & 4.133 & 0.595 & &
\end{tabular}




\begin{tabular}{|c|c|c|c|c|c|c|}
\hline \multirow{5}{*}{$\begin{array}{l}\text { Öğrenmeyi } \\
\text { Öğrenme } \\
\text { Yeterlikleri }\end{array}$} & 1 yildan az & 15 & 4.211 & 0.660 & \multirow{5}{*}{2.281} & \multirow{5}{*}{0.684} \\
\hline & $1-5$ y1l & 39 & 4.365 & 0.399 & & \\
\hline & 6-10 y1l & 30 & 4.364 & 0.537 & & \\
\hline & $11-15 \mathrm{y} 1 \mathrm{l}$ & 11 & 4.288 & 0.728 & & \\
\hline & $15 \mathrm{y} 11+$ & 26 & 4.151 & 0.637 & & \\
\hline \multirow{5}{*}{$\begin{array}{l}\text { İnisiyatif ve } \\
\text { Girişimcilik } \\
\text { Yeterlikleri }\end{array}$} & 1 yildan az & 15 & 4.282 & 0.677 & \multirow{5}{*}{2.848} & \multirow{5}{*}{0.584} \\
\hline & $1-5$ y1l & 39 & 4.482 & 0.428 & & \\
\hline & $6-10 \mathrm{y} 11$ & 30 & 4.404 & 0.555 & & \\
\hline & $11-15$ y1l & 11 & 4.293 & 0.818 & & \\
\hline & $15 \mathrm{yll}+$ & 26 & 4.261 & 0.549 & & \\
\hline \multirow{5}{*}{$\begin{array}{l}\text { Bilgiyi Elde Etme } \\
\text { Yeterliği }\end{array}$} & 1 yildan az & 15 & 3.978 & 0.972 & \multirow{5}{*}{9.788} & \multirow{5}{*}{0.044} \\
\hline & $1-5 \mathrm{y} 11$ & 39 & 4.389 & 0.560 & & \\
\hline & 6-10 yil & 30 & 4.122 & 0.783 & & \\
\hline & $11-15$ y1l & 11 & 4.182 & 0.743 & & \\
\hline & $15 \mathrm{y} 1++$ & 26 & 3.737 & 0.817 & & \\
\hline \multirow{5}{*}{ Dijital Yeterlikler } & 1 yildan az & 15 & 3.689 & 1.291 & \multirow{5}{*}{11.333} & \multirow{5}{*}{0.023} \\
\hline & $1-5$ y1l & 39 & 4.261 & 0.878 & & \\
\hline & 6-10 y1l & 30 & 3.928 & 1.028 & & \\
\hline & $11-15$ y1l & 11 & 3.985 & 0.947 & & \\
\hline & $15 \mathrm{y} 1++$ & 26 & 3.321 & 1.153 & & \\
\hline \multirow{5}{*}{$\begin{array}{l}\text { Karar Verebilme } \\
\text { Yeterliği }\end{array}$} & 1 yildan az & 15 & 4.183 & 0.782 & \multirow{5}{*}{6.410} & \multirow{5}{*}{0.171} \\
\hline & $1-5$ y1l & 39 & 4.372 & 0.535 & & \\
\hline & 6-10 y1l & 30 & 4.217 & 0.665 & & \\
\hline & $11-15$ y1l & 11 & 3.977 & 0.876 & & \\
\hline & $15 \mathrm{y} 11+$ & 26 & 3.914 & 0.778 & & \\
\hline \multirow{5}{*}{$\begin{array}{l}\text { Genel Yaşamboyu } \\
\text { Öğrenme } \\
\text { Yeterlikleri }\end{array}$} & 1 yıldan az & 15 & 4.094 & 0.659 & \multirow{5}{*}{6.832} & \multirow{5}{*}{0.145} \\
\hline & $1-5$ y1l & 39 & 4.377 & 0.359 & & \\
\hline & 6-10 y1l & 30 & 4.264 & 0.532 & & \\
\hline & $11-15$ yll & 11 & 4.228 & 0.652 & & \\
\hline & $15 \mathrm{y} 1 \mathrm{l}+$ & 26 & 3.997 & 0.614 & & \\
\hline
\end{tabular}




\section{Halk eğitim merkezinde görev yapan eğiticilerin yaşamboyu öğrenme} yeterlikleri algısının, eğitim düzeyine göre durumu. Araştırma bulgularına göre, çalışma grubunu oluşturan eğiticilerin eğitim düzeyleri ile genel yaşamboyu öğrenme yeterlikleri ve alt boyutlardan öğrenmeyi öğrenme, bilgiyi elde etme, dijital ve karar verebilme yeterlikleri arasında, istatistiksel açıdan anlamlı bir farklılık vardır. Tablo 9, katılımcıların yaşamboyu öğrenme yeterlik düzeylerinin eğitim durumuna göre ortalamalarını göstermektedir.

Tablo 9

Yaşamboyu Öğrenme Yeterliklerinin Ĕ̆itim Düzeyine Göre Durumu

\begin{tabular}{|c|c|c|c|c|c|c|}
\hline & Eğitim Düzeyi & $n$ & Ort. & ss & KW & $p$ \\
\hline \multirow{3}{*}{$\begin{array}{l}\text { Özyönetim } \\
\text { Yeterlikleri }\end{array}$} & Lise ve altı & 71 & 4.177 & 0.550 & \multirow{3}{*}{3.761} & \multirow{3}{*}{0.153} \\
\hline & Ön Lisans & 24 & 4.421 & 0.401 & & \\
\hline & Lisans ve üstü & 26 & 4.235 & 0.509 & & \\
\hline \multirow{3}{*}{$\begin{array}{l}\text { Öğrenmeyi } \\
\text { Öğrenme } \\
\text { Yeterlikleri }\end{array}$} & Lise ve altı & 71 & 4.159 & 0.610 & \multirow{3}{*}{10.330} & \multirow{3}{*}{0.006} \\
\hline & Ön Lisans & 24 & 4.587 & 0.283 & & \\
\hline & Lisans ve üstü & 26 & 4.388 & 0.467 & & \\
\hline \multirow{3}{*}{$\begin{array}{l}\text { İnisiyatif } \\
\text { Girişimcilik } \\
\text { Yeterlikleri }\end{array}$} & Lise ve altı & 71 & 4.290 & 0.618 & \multirow{3}{*}{4.705} & \multirow{3}{*}{0.095} \\
\hline & Ön Lisans & 24 & 4.620 & 0.305 & & \\
\hline & Lisans ve üstü & 26 & 4.372 & 0.515 & & \\
\hline \multirow{3}{*}{$\begin{array}{l}\text { Bilgiyi Elde Etme } \\
\text { Yeterliği }\end{array}$} & Lise ve altı & 71 & 3.873 & 0.775 & \multirow{3}{*}{22.876} & \multirow{3}{*}{0.000} \\
\hline & Ön Lisans & 24 & 4.681 & 0.484 & & \\
\hline & Lisans ve üstü & 26 & 4.244 & 0.704 & & \\
\hline \multirow{3}{*}{ Dijital Yeterlikler } & Lise ve altı & 71 & 3.484 & 1.030 & \multirow{3}{*}{36.116} & \multirow{3}{*}{0.000} \\
\hline & Ön Lisans & 24 & 4.806 & 0.404 & & \\
\hline & Lisans ve üstü & 26 & 4.109 & 1.075 & & \\
\hline \multirow{3}{*}{$\begin{array}{ll}\text { Karar } & \text { Verebil } \\
\text { Yeterliği } & \end{array}$} & Lise ve altı & 71 & 4.039 & 0.768 & \multirow{3}{*}{6.523} & \multirow{3}{*}{0.038} \\
\hline & Ön Lisans & 24 & 4.469 & 0.468 & & \\
\hline & Lisans ve üstü & 26 & 4.279 & 0.593 & & \\
\hline \multirow{3}{*}{$\begin{array}{l}\text { Genel Yaşamboyu } \\
\text { Öğrenme } \\
\text { Yeterlikleri }\end{array}$} & Lise ve altı & 71 & 4.067 & 0.574 & \multirow{3}{*}{19.019} & \multirow{3}{*}{0.000} \\
\hline & Ön Lisans & 24 & 4.585 & 0.269 & & \\
\hline & Lisans ve üstü & 26 & 4.294 & 0.479 & & \\
\hline
\end{tabular}

Tablo 9'da görüldüğü gibi, araştırmaya katılan eğitimcilerin "özyönetim yeterlikleri" ile "inisiyatif ve girişimcilik" yeterlikleri puan ortalamalarının, eğitim düzeyi değişkeni açısından grup ortalamaları arasındaki fark anlamlı bulunmamış, fakat, "öğrenmeyi öğrenme" yeterlikleri ortalamalarının eğitim düzeyi değişkeni açısından anlamlı bir farklılık bulunmuştur $(\mathrm{KW}=10.330 ; p=0.006<0.05)$. Buna göre, eğitim durumu ön lisans olanların öğrenmeyi öğrenme yeterlikleri puanları $(4.587 \pm$ 
0.283), eğitim durumu lise ve altı olanlar ile lisans ve üzeri eğitim düzeyi olanların öğrenmeyi öğrenme yeterlikleri puanlarından (4.159 \pm 0.610$)$ yüksek bulunmuştur. Katılımciların "bilgiyi elde etme", "dijital" ve "karar verebilme" yeterliklerinin de eğitim durumlarına göre anlamlı farklılık sergilediği görülmüştür. Bu yeterliklerde, ön lisans mezunu olan usta öğreticilerin yeterlik algısı, diğer eğitim düzeylerindekilere kıyasla daha yüksek bulunmuştur. Buna paralel olarak, lise ve altı düzeyde eğitimi olanların öğrenmeyi öğrenme, bilgiyi elde etme, dijital, karar verebilme ve genel yeterliklerinin ortalamaları da daha yüksek düzeyde eğitimi olanlardan düşüktür. $\mathrm{Bu}$ nedenle eğitim değişkeni, diğer değişkenlere göre, yaşamboyu öğrenme yeterliklerinin daha fazla alt boyutunda anlamlı farklılık sergileyen bir etken olmuştur. Sonuç olarak, eğitim durumu lise ve üzeri düzeyde olan eğiticilerin, lise ve altı düzeyde olanlardan daha fazla öğrenmeyi öğrenme, bilgiyi elde etme, dijital, karar verebilme ve genel yaşamboyu öğrenme yeterlikleri algısına sahip olduğu anlaşılmaktadır. Fakat, bu durum, "özyönetim yeterlikleri" ile "inisiyatif ve girişimcilik yeterlikleri" alt boyutlarında geçerli değildir.

\section{Halk eğitim merkezinde görev yapan eğiticilerin yaşamboyu öğrenme yeterlikleri algısının, bir eğitim seminerine katılmış olma deneyimine göre} durumu. Araştırma kapsamında, ilgili halk eğitimi merkezlerindeki eğiticilere dönük yetişkin eğitimi temel kuramları ve yöntemleri konulu seminer uygulaması yapılmıştır. Katılımcılar, ilk kez yetişkin eğitimi konulu bir seminere katıldığını beyan etmiştir. Bu nedenle, kişisel ve mesleki gelişime yönelik etkinliklerin ihmal edildiği düşünülen bu grubun, daha önce başka bir kişisel gelişim konulu veya mesleki seminere katılıp katılmadığının belirlenmesi de önem taşımaktadır.

Katılımcıların yaşamboyu öğrenme yeterliklerinin daha önceden bir seminere katılma deneyimine göre öğrenmeyi öğrenme, inisiyatif ve girişimcilik, bilgiyi elde etme, dijital, karar verebilme ve genel yaşamboyu öğrenme yeterliklerinin anlamlı bir farklılık göstermediği saptanmıştır. Bunun nedeninin, katılmış olunan seminer etkinliğinin içeriği veya katılımcılar için önemi olduğu ileri sürülebilir. Fakat, katılımcıların yalnızca "özyönetim yeterlikleri" ortalama puanlarının, seminere katılım deneyimine göre anlamlı bir farklılık sergilediği görülmüştür. Tablo 10, bu sonuçları yansitmaktadir.

Tablo 10'daki bulgulardan görüldüğü üzere, daha önceden bir eğitim seminerine katılmış eğiticilerin özyönetim yeterlik puanları ortalaması, katılmamış olanlardan daha yüksektir (Ort.=4.329; $p<0.05$ ). Buna dayanarak, seminere katılmış olma etkeninin, sadece özyönetim alt boyutuyla yaşamboyu öğrenme yeterliklerine etki edebildiği ileri sürülebilir. Seminer deneyiminin, diğer yeterlik boyutlarına göre anlamlı bir farklılık göstermemesinin nedenleri olarak, seminer konularının bireysel ihtiyaçlara uygun olmaması ve seminere gönülsüz katılım gibi etkenler sayılabilir. 
Tablo 10

Özyönetim Yeterliklerinin Seminer Deneyimine Göre Durumu

\begin{tabular}{|c|c|c|c|c|c|c|}
\hline & Katılma Durumu & $n$ & Ort. & ss & $M W$ & $p$ \\
\hline \multirow{2}{*}{ Özyönetim Yeterlikleri } & Katılmış & 79 & 4.329 & 0.462 & \multirow{2}{*}{214.000} & \multirow{2}{*}{0.015} \\
\hline & Katılmamış & 42 & 4.066 & 0.582 & & \\
\hline \multirow{2}{*}{ Öğrenmeyi Öğrenme Yeterlikleri } & Katılmış & 79 & 4.340 & 0.561 & \multirow{2}{*}{371.500} & \multirow{2}{*}{0.117} \\
\hline & Katılmamış & 42 & 4.204 & 0.539 & & \\
\hline \multirow{2}{*}{ İnisiyatif ve Girişimcilik Yeterlikleri } & Katılmış & 79 & 4.423 & 0.556 & \multirow{2}{*}{371.500} & \multirow{2}{*}{0.116} \\
\hline & Katılmamış & 42 & 4.278 & 0.559 & & \\
\hline \multirow{2}{*}{ Bilgiyi Elde Etme Yeterliği } & Katılmış & 79 & 4.129 & 0.720 & \multirow{2}{*}{653.500} & \multirow{2}{*}{0.976} \\
\hline & Katılmamış & 42 & 4.083 & 0.878 & & \\
\hline \multirow{2}{*}{ Dijital Yeterlikler } & Katılmış & 79 & 3.878 & 1.000 & \multirow{2}{*}{554.500} & \multirow{2}{*}{0.566} \\
\hline & Katılmamış & 42 & 3.885 & 1.231 & & \\
\hline \multirow{2}{*}{ Karar Verebilme Yeterliği } & Katılmış & 79 & 4.212 & 0.707 & \multirow{2}{*}{499.000} & \multirow{2}{*}{0.377} \\
\hline & Katılmamış & 42 & 4.107 & 0.690 & & \\
\hline \multirow{2}{*}{$\begin{array}{l}\text { Genel Yaşamboyu } \\
\text { Yeterlikleri }\end{array}$} & Katılmış & 79 & 4.264 & 0.524 & \multirow{2}{*}{426.500} & \multirow{2}{*}{0.205} \\
\hline & Katılmamış & 42 & 4.133 & 0.574 & & \\
\hline
\end{tabular}

\section{Sonuç ve Tartışma}

Yukarıda yer verilmiş olan bulgular, çalışma grubundaki eğiticilerin yaşamboyu öğrenme yeterliklerine ilişkin genel bir profilin betimlenmesini sağlamıştır. Eğiticilerin eğitimi çalışmalarının, yaşamboyu öğrenme yeterliklerinin gelişmesine ve bu yeterliklere ilişkin algının artmasına katkı yapacağını varsaydığımızda, bu çalışmanın bulgularını yansıtan eğitimci grubunun, düşük eğitim düzeyine rağmen sahip olduğu beceri ve yeterliklerle dikkat çektiği söylenebilir.

Halk eğitimi merkezleri, hem eğiticilerin eğitimi hem de yaşam boyu öğrenme yeterlikleri odağında önemli bir konuma sahiptir. Bu merkezlere dönük son yıllarda yapılmış araştırmalar personel nitelikleri, eğitim materyali ve yönetsel yapıyla bağlantılı kronikleşmiş sorunları sergilemiştir (Sabanc1 \& Rodoplu, 2013; Ural \& Akbaş, 2009; Yayla, 2009). Milli Eğitim Bakanlığı'nın hayat boyu öğrenme stratejisi belgesinde yer alan bireyin bilgi, beceri, ilgi ve yeterliklerini geliştirmek amacıyla hayatı boyunca katıldığı her türlü öğrenme etkinlikleri (Coşkun \& Demirel, 2012) tanımı, bu tür etkinlikler düzenlemekle yükümlü kurumlardan biri olan bu merkezlere gösterilmesi gereken ilgiyi vurgular niteliktedir.

Araştırmada kullanılmış olan ölçek, içerik açısından hem OECD (2005)'nin hem de Avrupa Komisyonu'nun kabul ettiği temel yeterlikleri-8 temel yeterlik- (Otten \& Ohana, 2009) kapsamaktadır. Fakat, bu tür alg1 ölçeklerinin, bireylerin öznel değerlendirmelerini yansıttığı göz önüne alınarak karar süreçlerinde kullanılması önerilir. 
Çalışma grubunun demografik profiline bakıldığında, ağırlıklı olarak 31-50 yaş aralığında ve yarıdan fazlasının lise ve altı düzeyinde bir eğitim geçmişinin bulunduğu bir eğitim personeli görülmüştür. Bu personelin eğiticilik yaptığı mesleki alanların büyük bölümü, el sanatları ve el becerileri başlığı altında toplanabilecek alanlardan oluşmaktadır. Öğreticilik deneyimi açısından ise, katılımcıların yaklaşık üçte birinin 1-5 y1l arası, dörtte birinin ise 6-10 y1l arası deneyimi vardır. Yeterliklerle bir bağlantısı olabileceği tahmin edilen bir değişken olan seminere katılım deneyiminin ise, katılımcıların üçte ikisinde var olduğu görülmüş̧ür. Dolayısıyla, görece düşük eğitimli ve az deneyimli bir öğretici kitlesi söz konusudur.

Araştırma amaçlarının ilki olan, halk eğitim merkezinde görev yapan eğiticilerin yaşamboyu öğrenme yeterlik düzeyi algısı, (dijital yeterlikler hariç) hem alt boyutlar hem de genel yeterlik düzeyi açısından çok yüksek çıkmıştır. Dijital yeterliklerin yüksek bulunmasına karşın, diğerlerine göre daha düşük olmasının iletişim, bilgisayar ve internet teknolojilerindeki gelişmelere uyum sağlamanın zorluğundan kaynaklandığ1 düşünülmektedir. Yetişkin eğitimi ve yaşamboyu öğrenmeyle bağlantılı bir eğitim alt yapısından uzak olan eğiticilerin, genel yaşamboyu öğrenme yeterliklerinin çok yüksek bulunmasının nedenleri, yeni araştırmaların konusudur. Çünkü, böyle bir yüksek yeterlik algısı, halk eğitimi merkezlerinin sorunlarına dönük geçmiş araştırmaların bulgularıyla uyumlu değildir.

Araştırmanın ikinci amacı olan halk eğitim merkezinde görev yapan eğiticilerin yaşamboyu öğrenme yeterlikleri algısının yaş ve cinsiyet değişkenlerine göre durumu ise, hem alt boyutlar hem de genel yeterlik algısı açısından farklılıklar sergilemektedir. Öncelikle, katılımcıların yaşı ile bilgiyi elde etme, dijital yeterlikler, karar verebilme ve genel yeterlikler ortalamaları arasında anlamlı farklılık saptanmıştır. 35 yaş altındaki eğiticilerin bilgiyi elde etme, karar verebilme ve dijital yeterlikleri, diğer yaş gruplarından yüksek bulunduğundan dolayı, görece günümüz teknolojilerine daha yakın olabilen genç eğiticilerin, bilgi ve iletişim teknolojilerini kullanarak bilgiye daha rahat ulaşabildiği ve buna dayanarak kararlar alabilmeyi de başardığ 1 savunulabilecektir. Bulgulara göre, cinsiyetin, yaşamboyu öğrenme yeterlikleri üzerine bir etkisi olduğu söylenememektedir. Fakat, bu durum, çalışma grubunu oluşturan katılımcıların büyük çoğunluğunun kadınlardan oluşmasından kaynaklanmıştır. Öte yandan, bu bulgu, Konokman ve Yelken (2014)'in öğretim elemanlarına dönük çalışmasındaki, kadın eğitimcilerin yüksek yeterlik algısı bulgusuyla uyumludur.

Halk eğitim merkezinde görev yapan eğiticilerin mesleki deneyimine göre yaşamboyu öğrenme yeterlikleri durumuyla ilgili üçüncü amaca dönük bulgular da, bazı alt boyutlar bazında anlamlı değişimleri yansıtmıştır. Katılımcıların mesleki deneyimi ile dijital yeterlikleri ve bilgiyi elde etme yeterliği arasında anlamlı bir farklılıktan söz edilebilmekteyken, diğer yeterlikler ve genel yaşamboyu öğrenme yeterliği algısı arasında anlamlı bir farklılık bulunamamıştır. Mesleki deneyimi 1-5 yıl arasında olan eğiticilerin hem bilgiyi elde etme hem de dijital yeterlikler algısı diğer tüm yaş gruplarından daha yüksek; deneyimi 15 yıldan fazla olan katılımcıların bu iki alt boyuttaki yeterlik algıları ise, diğer tüm gruplardan daha düşük olmuştur. Bu durum, 
bilgiyi elde etme ve dijital yeterlikler arasındaki yüksek pozitif yönlü bağlantıyı doğrularken, öğreticilik deneyimindeki artışın, bilgiyi elde etme ve dijital yeterlikler algısını yükseltmediğini göstermektedir. Böyle bir sonucun nedenleri arasında, günümüz iletişim teknolojilerini daha etkin ve kolay kullanabilme becerisinin, daha genç ve dolayısıyla daha az deneyimli bireylerde bulunması gösterilebilir.

Araştırmanın dördüncü amacına dönük bulgular çerçevesinde, eğiticilerin eğitim düzeyinin yaşamboyu öğrenme yeterliklerine etkisi incelenmiştir. Bulgular, katılımcıların eğitim düzeyinin, genel yaşamboyu öğrenme, öğrenmeyi öğrenme, bilgiyi elde etme, dijital ve kara verebilme yeterliklerini etkileyebildiğini göstermiştir. Eğitim durumu lise ve üzeri düzeyde olan eğiticilerin, lise ve altı düzeyde olanlardan daha fazla öğrenmeyi öğrenme, bilgiyi elde etme, dijital, karar verebilme ve genel yaşamboyu ögrenme yeterlikleri algısına sahip olduğu anlaşılmaktadır. Fakat, eğitim düzeyi grupları arasında en yüksek ortalama puanı, ön lisans düzeyinde eğitimi olanlardadır. Bununla birlikte, eğitim düzeyinin, hem genel yaşamboyu öğrenme yeterliklerinde hem de alt boyutların çoğunluğunda en etkili değişken olduğu görülmüştür. Bu durumun, Şahin ve Arcagök (2014)'ün ilköğretim öğretmenlerine dönük araştırmasında, öğretmenlerin bilgiyi elde etme ve dijital yeterliklerinin, eğitim düzeyi ve mesleki kıdem düzeyine göre anlamlı farkl1lıklar gösterdiği bulgusuyla uyumlu olduğu söylenebilir. Öte yandan, eğitim düzeyinin, özyönetim ile inisiyatif ve girişimcilik yeterlikleri algısında neden etkili olamadığı da, bulguların diğer yönüne işaret etmektedir. Bu sonuç, özyönetim alg1sı ile bireysel inisiyatif gücünün, örgün eğitimin etki alanı dışındaki ailevi veya toplumsal etkenlerle biçimlenebildiğinin bir göstergesi sayılabilir.

Son olarak, katılımcıların seminer deneyiminin yaşamboyu öğrenme yeterlikleri algısına etkisiyle ilgili bulgulara bakıldığında, katılımcıların bir eğitim seminerine katılma deneyimi ile özyönetim yeterlikleri arasında anlamlı bir farklılık görülmüştür. Daha önceden bir eğitim seminerine katılım deneyimi olanların özyönetim yeterlik puanları, katılmamış olanlara kıyasla daha yüksek bulunmuştur. Bu sonuç, diğer yeterlikler açısından olmasa da, eğitim semineri etkinliğinin, bireysel özyönetim yeterliklerine etki edebildiğini göstermektedir.

\section{Öneriler}

Yukarıdaki bulgulara dayanarak, yaşamboyu öğrenmeye ilişkin yeterlik algısının hangi bireysel etkenlerle birlikte değişebildiğinin ve bunun ne tür sonuçlara yol açtığının, zaman serisi analizleriyle izlenmesi gerektiği savunulabilir. Öğrenmeyi öğrenme, bilgiyi elde etme ve dijital yeterliklerle ilgili becerilerin yaşamboyu öğrenme süreçlerinde oynadığı rolün kritik olması nedeniyle, bu alandaki yeterliklerin geliştirilmesine yönelik eğitim politikalarına dikkat çekilmelidir. Bu bulgular, çok işlevli, ama dar etkili halk eğitimi merkezlerinde görev yapan eğitim personelinin profiline, bir başka açıdan 1şık tutmuştur.

Gelecekteki araştırmalarda, OECD'nin DeSeCo projesinde tanımlanmış olan üçlü yapı temelinde geliştirilmiş başka ölçeklerin de uygulanması yoluyla halk eğitim merkezlerinin eğitim personelinin tanımlanması olanaklıdır. Özellikle, AB'nin 
yaşamboyu öğrenme felsefesi için önerdiği yeterliklerin hedeflediği yurttaş modeline ulaşabilmenin, o yeterliklere sahip eğiticilerin yetiştirilebilmesine bağlı olduğu açıktır.

$\mathrm{Bu}$ araştırmanın bulgularına dönük öneriler şöyle özetlenebilir:

- Donanım, müfredat ve sistem kaynaklı sıkıntılar yaşadığ 1 kabul edilen halk eğitimi merkezi eğiticilerinin, hem alt boyutlar hem de genel yeterlik düzeyi açısından yüksek düzeyde yeterlik algısına neden sahip olduğunun tanımlanması gerekir. Böylece, bireysel ve mesleki sorunlar ile yaşamboyu yeterlik algısı arasındaki ilişkinin varlığına ve yönüne göre değişen stratejiler ve politikalar geliştirilebilir.

- Halk eğitimi merkezlerinde görev yapan eğiticilerin mesleki deneyim süresinin, yaşamboyu öğrenme yeterliklerinin tüm boyutlarıyla neden anlamlı bir değişim sergilemediğine yönelik yeni çalışmalar, mesleki deneyim etkeninin yaşamboyu öğrenme becerilerindeki etkisine 1şık tutacaktır.

- Eğitim düzeyi ile yaşamboyu öğrenme yeterliklerine ilişkin bulgular, örgün eğitim sisteminin kazanımlarının yeniden değerlendirilmesi veya yenilenmesi gerekliliğini işaret ediyor olabilir. Bu nedenle, farklı eğitim düzeylerindeki halk eğitimi merkezi eğiticilerinin bireysel olarak izlendiği nitel araştırmalar daha işlevsel olabilecektir. 


\section{Kaynakça}

Altunışık, R., Coşkun, R., Bayraktaroğlu, S. \& Yıldırım, E. (2010). Sosyal bilimlerde araştırma yöntemleri- SPSS uygulamalı (6. baskı). Adapazarı: Sakarya Yayıncılık.

Bieschke, K. J. (2006). Research self-efficacy beliefs and research outcome expectations: Implications for developing scientifically minded psychologists. Journal of Career Assessment, 14(1), 77-91. doi: 10.1177/1069072705281366

Budak, Y. (2009). Yaşamboyu öğrenme ve ilköğretim programlarının hedeflemesi gereken insan tipi. Gazi Eğitim Fakültesi Dergisi, 29(3), 693-708.

Coşkun, D. Y. \& Demirel, M. (2012). Üniversite öğrencilerinin yaşamboyu öğrenme eğilimleri. Hacettepe Üniversitesi Ĕ̈itim Fakültesi Dergisi, 42, 108-120.

Çelikkaleli, Ö. (2011). Yetişkin eğitimcisi öğretmenlerin tükenmişlik ve mesleki yetkinliklerinin incelenmesi. Mehmet Akif Ersoy Üniversitesi Sosyal Bilimler Enstitüsü Dergisi, 3(4), 38-53.

Demircioğlu, H. \& Ömeroğlu, E. (2014). Eğitici anne eğitimi ve anneden anneye eğitim yaklaşımlarının annelerin işlevleri ve çocuk yetiştirme tutumları üzerindeki etkisi. Kuram ve Uygulamada Eğitim Bilimleri, 14(4), 1439-1465. doi: 10.12738/estp.2014.4.2114

Geyik, M. F., Kara, İ. H., Uzunlar, A. K., Baltacı, D., Gönen, İ. ve diğerleri. (2013). Tıp fakültesi öğretim üyelerine uygulanan eğiticilerin eğitimi etkinliğinin araştırılması. Konuralp Tip Dergisi, 5(3), 24-28.

Karakuş, C. (2013). Meslek yüksekokulu öğrencilerinin yaşamboyu öğrenme yeterlikleri. Ĕ̈itim ve Öğretim Araştırmaları Dergisi, 2(3), 26-35.

Kılıç, Ç. (2010). Aile eğitim programları ve Türkiye'deki örnekleri. Abant İzzet Baysal Üniversitesi Dergisi, 10(1), 99-111.

Konokman, Y. G. \& Yelken Yanpar, T. (2014). Eğitim fakültesi öğretim elemanlarının yaşam boyu öğrenme yeterliklerine ilişkin algıları. Hacettepe Üniversitesi Ĕ̆itim Fakültesi Dergisi, 29(2), 267-281.

Kurt, T. (2012). öğretmenlerin özyeterlik ve kolektif yeterlik algıları. Türk Ĕgitim Bilimleri Dergisi, 10(2), 195-227.

Machala, D. \& Horvat, A. (2010). Competency based lifelong learning of librarians in Crotia: An integrative approach. Paper presented at IFLA Satellite Meeting: Cooperation and Colloboration in Teaching and Research-Trends in Library and Information Studies Education, 8-9 August 2010, Boras-Sweden. Retrieved from www.eprints.rclist.org/18148/1/6-12-1-PB.pdf

McCoach, D. B. \& Colbert, R. D. (2010). Factors underlying the collective teacher efficacy scale and their mediating role in the effect of socioeconomic status on academic achievement at the school level. Measurement and Evaluation in Counseling and Development, 43(1), 31-47. doi: 10.1177/0748175610362368

Martinez-Mediano, C. \& Lord, S.M. (2012). Lifelong learning competencies program for engineers. International Journal of Engineering Education, 28(1), 130-143. 
Milli Eğitim Bakanlı̆̆ı, (2010). Yaygın Eğitim Kurumları Yönetmeliği, 27587. www.mevzuat.meb.gov.tr adresinden alınmıştır.

Organization for Economic Cooperation and Development (OECD), (2005). The Definiton and Selection of Key Competencies- Executive Summary. Retrieved from www.oecd.org/pisa/35070367.pdf adresinden alınmıştır.

Otten, H. \& Ohana Y. (2009). The eight key competencies for lifelong learning: An appropriate work within which to develop the competence of trainers in the field of european youth work or just plain politics? European Commission, Salto-Youth Training and Cooperation Resource Centre and IKAB. Retrieved from www.ikab.de/reports/Otten_Ohana_8keycompetence_study_2009.pdf.

Sabanc1, A. \& Rodoplu, D. E., (2013). Halk eğitim merkezlerinin denetiminde karşılaşılan sorunlar. E-international Journal of Educational Research, 4(2), 61-77.

Seferoğlu, S. S. (2004). Öğretmen yeterlilikleri ve mesleki gelişim. Bilim ve Aklın Aydınlı̆̆ında Ĕ̈itim, 58, 40-45.

Selvi, K. (2011). Teachers' lifelong learning competencies. Uluslararası Eğitim Programları ve Öğretim Çalışmaları Dergisi, 1(1), 61-69.

Soran, H., Akkoyunlu, B. \& Kavak, Y. (2006). Yaşamboyu öğrenme becerileri ve eğiticilerin eğitimi programı: Hacettepe üniversitesi örneği. Hacettepe Üniversitesi Ĕ̈itim Fakültesi Dergisi, 30, 201-210.

Şahin, Ç. \& Arcagök, S. (2014). Öğretmenlerin yaşamboyu öğrenme yeterlikleri düzeyinin çeşitli değişkenler açısından incelenmesi. Adlyaman Üniversitesi Sosyal Bilimler Enstitüsü Dergisi, 7(16), 394-416.

Türkiye İstatistik Kurumu, (2013). Yaygın ĕgitim istatistikleri 2012/2013 (Yayın No: 4354- ISSN:1300-1027). www.tuik.gov.tr adresinden alınmıştır.

Türkoğlu, A. \& Uça, S. (2011). Türkiye'de halk eğitimi: Tarihsel gelişimi, sorunları ve çözüm önerileri. Adnan Menderes Üniversitesi Eğitim Fakültesi Eğitim Bilimleri Dergisi, 2(2), 48-62.

Ural, U. \& Akbaş, V. (2009). Halk eğitim merkezlerinde eğitici personel adaylarının seçim süreci. www.eab.org.tr/eab/2009/pdf/153.pdf adresinden alınmıştır.

Uysal, İ. (2013). Akademisyenlerin genel öz-yeterlik inançları: AİBÜ eğitim fakültesi örneği. Trakya Üniversitesi Eğitim Fakültesi Dergisi, 3(2), 144-151.

Uzunboylu, H. \& Hürsen, Ç. (2011). Lifelong learning competence scale (LLLCS): The study of validity and reliability. Hacettepe Üniversitesi Ĕ̈itim Fakültesi Dergisi, 41, 449-460.

Yayla, D. (2009). Türk yetişkin eğitimi sisteminin değerlendirilmesi. Ankara: Milli Eğitim Bakanlığı Eğitimi Araştırma ve Geliştirme Dairesi Başkanlığı. http://www.meb.gov.tr/earged/earged/Yetiskin_Egitimi.pdf adresinden alınmıştır.

Yeşilyurt, E. (2013). Academic self-efficacy perceptions of teacher candidates. Mevlana International Journal of Education, 3(1), 93-103. 